SAND9 $1-7011$

Unlimited Release

UC -275

\title{
Advanced Photovoltaic Concentrator System Low-Cost Prototype Module
}

Neil R. Kaminar, John McEntee, Don Curchod

Solar Engineering Applications Corporation

2010 Fortune Drive, Suite 102

San Jose, CA 95131

Pitpared by Sandia National Laboratories Albuquerque. New Mexico 87185

and Livermore. California 94550 for the United States Department of Energy

under Contract DE-ACO4-76DP00789

Printed September 1991 
Issued by Sandia National Laboratories, operated for the United States Department of Energy by Sandia Corporation.

NOTICE: This report was prepared as an account of work sponsored by an agency of the United States Government. Neither the United States Government nor any agency thereof, nor any of their employees, nor any of their contractors, subcontractors, or their employees, makes any warranty, express or implied, or assumes any legal liability or responsibility for the accuracy, completeness, or usefulness of any information, apparatus, product, or process disclosed, or represents that its use would not infringe privately owned rights. Reference herein to any specific commercial product, process, or service by trade name, trademark, manufacturer, or otherwise, does not necessarily constitute or imply its endorsement, recommendation, or favoring by the Uniter States Government, any agency thereof or any of their contractors or subcontractors. The views and opinions expressed herein do not necessarily state or reflect those of the United States Government, any agency thereof or any of their contractors.

Printed in the United States of America. This report has been reproduced directly from the best available copy.

Available to DOF and DOE contractors from

Office of Scientific and Technical Information

PO Box 62

Oak Ridge. TN 378.31

Prices available from $(615) 576-8401$, FTS 626-8401

Available to the public from

National Technical Information Service

US Department of Commerce

5285 Port Roval Rd

Springfield, VA 22161

N'TIS price codes

Printed copy: A06

Microfiche copy: A01 


\title{
ADVANCED PHOTOVOLTAIC CONCENTRATOR SYSTEM LOW-COST PROTOTYPE MODULE
}

\author{
N. R. Kaminar, J. McEntee, D. Curchod \\ Solar Engineering Applications Corporation \\ 2010 Fortune Drive, Suite 102 \\ San Jose, CA 95131
}

Sandia Contract: 05-4239C

\begin{abstract}
This report describes the continued development of an extruded lens and the development of a PV receiver, both of which will be used in the Solar Engineering Applications Corporation (SEA) 10X concentrator. These efforts were part of a pre-Concentrator Initiative Program. The 10X concentrator consists of an inexpensive, extruded linear Fresnel lens which focuses on one-sun cells which are adhesive-bonded to an anodized aluminum heat sink. Module sides are planned to be molded along with the lens and are internally reflective for improved on- and off-track performance. End caps with molded-in bearings complete the module. Ten modules are mounted in a stationary frame for simple, single-axis tracking in the east-west direction. This configuration, an array, is shipped completely assembled and requires only setting on a reasonably flat surface, installing 4 fasteners, and hooking up the wires. Development of the 10inch wide extruded lens involved one new extrusion die and a series of modifications to this die. Over $76 \%$ lens transmission was measured which surpassed the program goal of $75 \%$. One-foot long receiver sections were assembled and subjected to evaluation tests at Sandia National Laboratories. A first group had some problem with cell delamination and voids but a second 5 roup performed very well, indicating that a full size receiver would pass the full qualification test. Cost information was updated and presented in the report. The cost study indicated that the Solar Engineering Applications Corporation concentrator system can exceed the DOE electricity cost goals of less than $6 \notin$ per KW-hr.




\section{ACKNOWLEDGMENTS}

This program was a collaborative effort between Solar Engineering Applications Corporation and Sandia National Laboratories. The authors would like to thank those persons at Sandia National Laboratories who have contributed to this program in the form of testing support, critical comments and encouragement. 'These persons include, but are not limited to: Charles Stillwell, Fldon Boes, Bill Boyson, Jack Cannon, Jay Chamberlin, James Gee, Berry Hansen, Dave Hasti, Hugh Jones, Dave King, Rod Mahoney, Alex Maish, Elizabeth Richards, Douglas Ruby, Don Sharp, Phillip Walkington, and Marjorie Whipple.

In addition, the authors would like to thank L. Scott Leishman of AllWest Plastics for his help with extruding the lenses and Julio Bragagnolo of AstroPower for assistance with cells. 
TABLE OF CONTENTS

1.0 Introduction

Purpose

Description of SEA 10X Module

2.0 Lens Development

2.1 Objectives

2.2 Methods

2.2.1 Preliminary Molding with 7-Inch Lens

2.2.2 Design of 10 -Inch Lens

2.2.3 Molding of 10-Inch Lens

2.2.4 Hail Tests

2.3 Results

2.3.1 Molding

2.3.2 Hail Tests

5

6

6

6

9

14

17

17

17

3.0 Receiver Development

19

3.1 Objectives

21

3.2.

3.2.1 Heat Sink

3.2.1.1 Heat Sink Design

21

21

3.2.1.2 Heat Sink Manufacturing $\quad 26$

3.2.1.3 Heat Sink Testing 28

3.2.1.4 Heat Sink Test Results $\quad 30$

3.2.2 Cell String 31

3.2.2.1 Cells 32

3.2.2.2 Leads 34

3.2.2.3 Diodes 36

3.3 Assembly

3.3.1 First Group $\quad 40$

3.3.2 Second Group $\quad 41$

3.4 Testing

3.5 Results

3.5.1 First Group 48

3.5.2 Second Group $\quad 50$

4.0 Updated Costing 53

4.1 Electrical Energy Costs

4.2 Module Performance 54

4.3 Summary of Costs $\quad 55$

4.4 Discussion of Costs 57

5.0 Conclusions and Recommendations $\quad 59$

Appendix A, SEA 10 X Concentrator Drawings 61 


\section{FIGURES}

\section{Figure}

1 SEA $10 X$ Module

2 SEA 10X Concentrator Array

3 Cross Section of 7-inch Wide Lens Mod 16.1

Die Plates for 7-inch Wide Lens

Cross Section of Molded 7-inch Lens

Cost verses Lens Size

Cross Section of 10-inck. Wide Lens Mod 20.4

Off-Track Ray Trace

9 Calculated Off-Track Performance in the East-West Direction 12

Page

3

4

5

7

8

10 Calculated Performance with Different Apparent Sun Angles 12

11 Apparent North-South Declination Sun Angle 13

12 Photo of Extrusion Process 15

13 Die Shape for Proper Fresnel Shape 16

14 Results of Development of the Extrusion Die 18

15 Original Extruded Aluminum Heat Sink 23

16 Sheet Aluminum Heat Sink 24

17 Electricity Cost Calculation for Different Heat Sinks 25

18 Thermal Couple Placement 28

19 Heat Sink Test Setup 29

20 Module Wiring Diagram $\quad 31$

21 Receiver Section Wiring 32

22 Performance of Two One-Sun Cells at Low Concentration 33

23 Sea World Cell 33

24 Typical IV Curve for Sea World Cell

25 Cell Leads $\quad 35$

26 Cell Lead Interconnect $\quad 36$

27 Unpackaged Chip Diode $\quad 37$

28 Prototype Diode Packaging 38

29 Diode Leads 39

30 AstroPower Cell 41

31 RTV Pattern Used to Exclude Air 43

32 Environmental Test Flow Diagram 46

33 Receivers Under Test 47 


\section{TABLES}

Table

1 Results of Anodizing Vendor Qualification Testing

2 Heat Sink Test Results

3 Summary of Receiver Assembly Materials

4 Receiver Leakage Current @ $2200 \mathrm{~V}$ for the $1^{\text {st }}$ Group of Receivers

5 Receiver Leakage Current @ $2200 \mathrm{~V}$ for the 2nd Group of Receivers

6 Eiectricity Cost

7 Summary of System Costs

8 Cost per Watt

9 Summary of Module Costs

10 Summary of Array Costs

11 Summary of Field Costs 


\subsection{Introduction}

\section{Purpose}

The fuel for solar energy, sunlight, is free and abundant. The cost of electricity generated by photovoltaics (PV) is thus dependent on the cost of the equipment, installation and operation. Over the long run, the cost of electricity from traditional sources has been increasing, while the cost of electricity from PV has been decreasing. In certain applications, such as remote power, PV already competes favorably with other sources of electricity. It is inevitable that, as this trend continues, there will be a point of rapid expansion of PV markets.

Besides monetary considerations, there are social and ecological costs associated with using fossil and nuclear fuels that are being passed on to our children and grandchildren. Predictions forecast that the earth will be warmer in the year 2020 than it has been in 120,000 years because of the much publicized "greenhouse effect," the results of which will be damaging to humanity for many generations. ${ }^{1}$ Likewise, the extremely toxic waste from nuclear power plants will be with us for many generations.

From their inception, concentrators have held the promise of reducing the cost of PV systems. Expensive cell area can be replaced by inexpensive optical material. In the past, there have been problems with high cost and with the perception of reduced reliability due to increased complexity over flat-plate systems. The Solar Engineering Applications Corporation (SEA) low-cost 10X concentrator offers a solution to these problems.

SEA has focused its problem-solving design on the reduction of a concentrator system to its simplest and most easily produced form using:

1. The most cost-effective overall design.

2. The most cost-effective cells.

3. The most cost-effective production methods.

${ }^{1}$ D.E. Carlson, "Fossil Fuels, The Greenhouse Effect and Photovoltaics," Proc, 20th IEEE Photoveltaic Soecialists Conference, (IEEE Publishing Services, New York, New York, 1988). 
SEA believes that, once in production, the SEA $10 \mathrm{X}$ concentrator will be costcompetitive with all other forms of energy, including fossil fuels, selling for approximately one dollar per watt and producing electrical energy for under 6థ per kilowatt-hour. Full commercialization is planned by 1995 .

This report describes the continued development of an extruded lens and the development of a PV receiver, both of which will be used in the SEA 10X concentrator. These efforts were part of a pre-Concentrator Initiative Program.

\section{Description of SEA 10X Module}

The SEA 10X PV concentrator module is a state-of-the-art system that utilizes existing technology and materials to make the most cost-effective design available today. It is the first PV concentrator to be conceived wholly as a commercial product.

The module, shown in figure 1, consists of an inexpensive, extruded, linear-focus Fresnel lens, which focuses on a string of inexpensive and readily available onesun cells that are adhesive-bonded to an aluminum heat sink. The aluminum heat sink is anodized, which, in combination with the RTV adhesive, provides the necessary electrical standoff. Module sides are planned to be molded along with the lens and are made fully internally reflective by a thin aluminum film which acts as a secondary optical element to provide improved on- and off-track performance. End caps with molded-in bearings complete the module assembly. The total module length is 105 inches with the receiver being only 96 inches long.

The 10-module concentrator array, shown in figure 2 , uses simple, single-axis tracking in the east-west direction and inexpensive construction. The lightweight array frame is stamped from environmentally protected steel. The arrays are shipped completely assembled and require only being set on a reasonably flat surface, installing four fasteners, and hooking up the wires. 


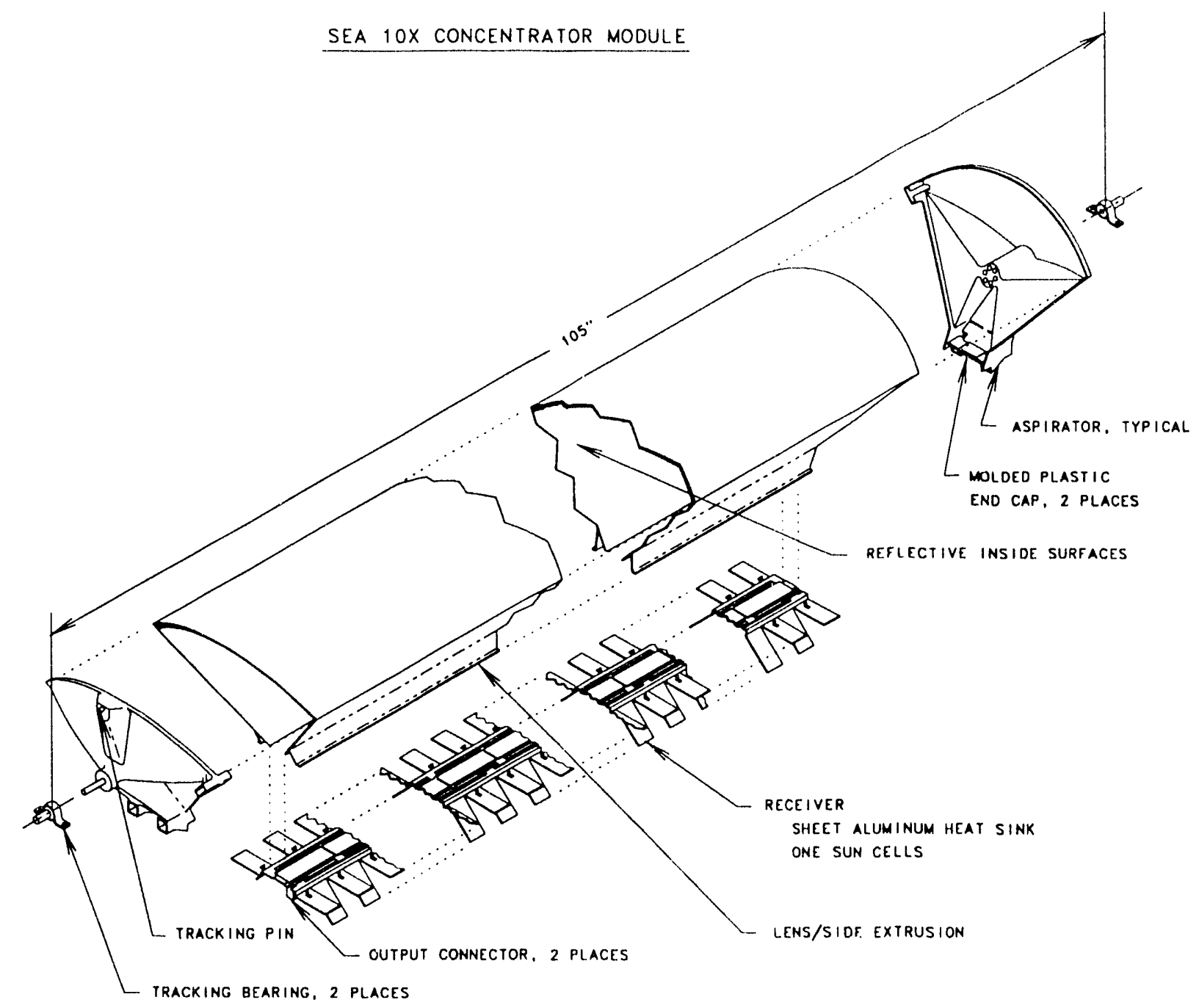

Figure 1. SEA 10X Module 


\section{SEA $10 X$ CONCENTRATOR ARRAY}

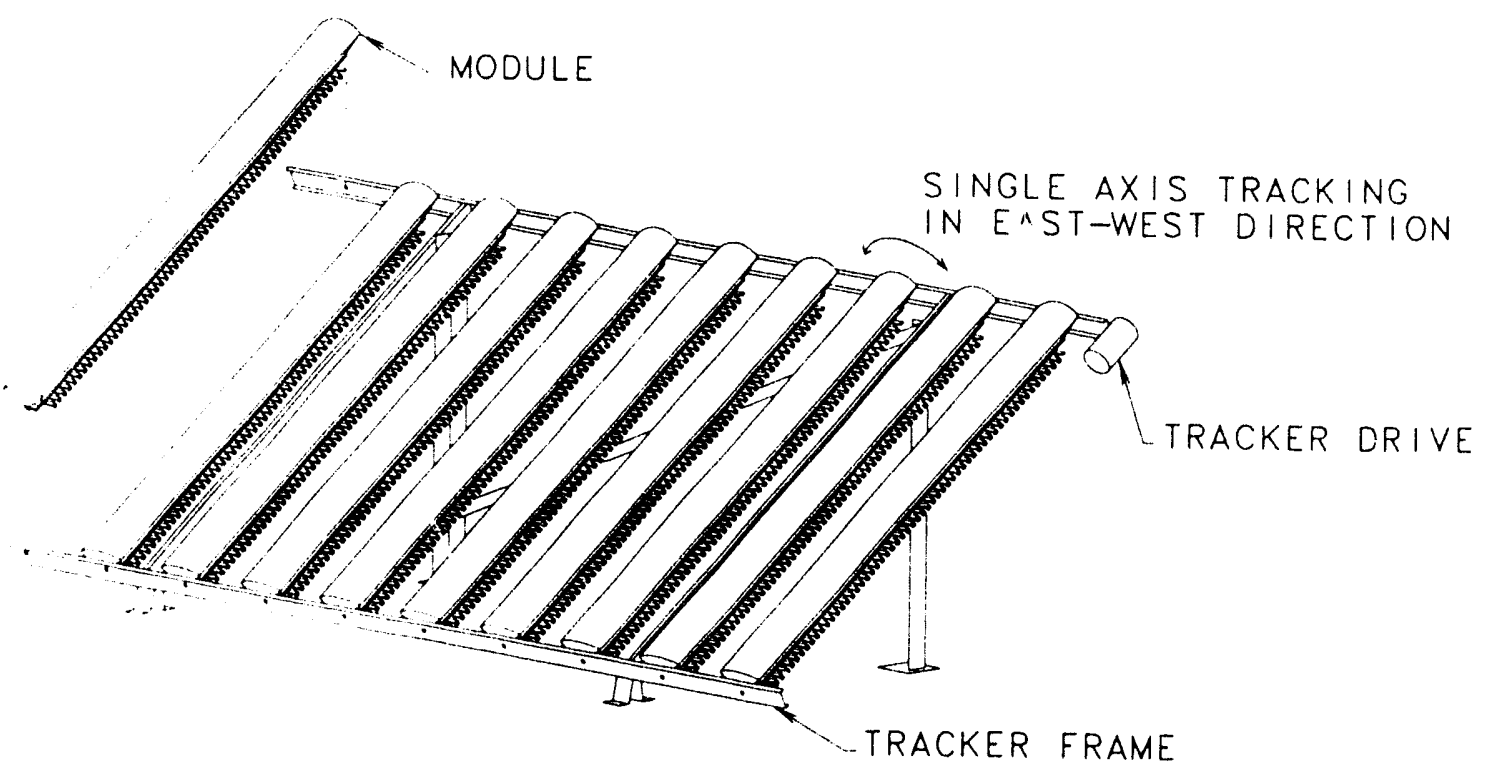

Figure 2. SEA 10X Concentrator Array 


\subsection{Lens Development}

Previous lens development was performed under contract with Sandia National Laboratories. ${ }^{2}$ This was SEA's first attempt at extruding a curved Fresnel lens, although design efforts were started in 1986. A cross section of this lens design can be seen in figure 3 and in drawing 10004 in Appendix A. The lens was 7 inches wide. The goal of this previous program was $70 \%$ optical transmission. An optical transmission of $71 \%$ was measured for this lens at Sandia.

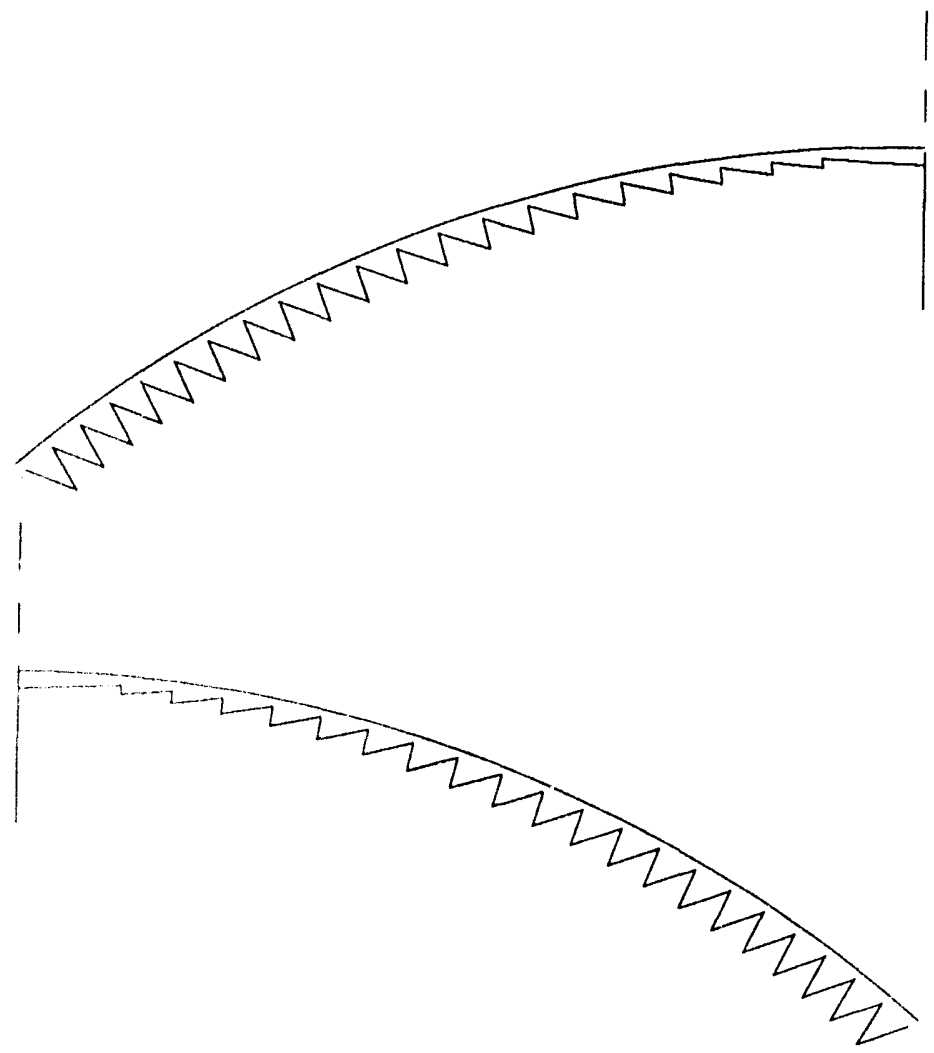

Figure 3. Cross Section of 7-inch Wide Lens Mod 16.1

2 Neil Kaminar and Don Curchod, The Design. Testing and Fabrication of an Extruded. Linear Focus Fresnel Lens, SAND90-7032 (Albuquerque: Sandia National Laboratories, 1990). 


\subsection{Objectives}

One basic objective of this program was to continue development of the extruded Fresnel lens. The goal of $75 \%$ optical transmission was established. Although this transmission figure seems low when compared with lenses manufactured by other methods, optical transmission is not a significant cost driver for the SEA $10 \mathrm{X}$ concentrator. Since the extruded lens is inexpensive, additional lens area can simply be $a^{\prime}$ ied to bring the flux on the cell up to the desired level. ${ }^{3}$

Two fall-back options were identified in case significant progress on the extruded lens was not achieved. One was to adopt a 3M lens to the SEA 10X concentrator design by bonding the 3M Lens Filmtm to the inside surface of a curved extrusion. ${ }^{4}$ The second option was to develop a post-extrusion forming machine that would reform the acrylic lens while the material was still hot. Past experience with prototypes of this machine showed significant improvement in Fresnel lens facet profile. ${ }^{5}$

\subsection{Methods}

\subsubsection{Preliminary Molding with 7-Inch Lens}

The initial effort under this contract was an attempt to improve the optical transmission of the 7 -inch wide lens developed under a previous contract which had been molded using an extrusion machine with a 2.5-inch diameter extrusion screw with a 20:1 length/diameter (L/D) ratio. The decision was made to move the tooling to an extrusion machine with a larger screw of 3.5-inch diameter and a 30:1 (L/D) ratio. Mechanical problems with this extrusion machine forced us to compromise and use a slightly smaller screw size of 3-inch diameter with a 24:1 $\mathrm{L} / \mathrm{D}$ ratio. Additional heating elements were added to the die to get a better "fill." A picture of the die plate can be seen in figure 4 .

\footnotetext{
${ }^{3}$ This line of reasoning is different than what is normally used in concentrator design. The lens area is normally held constant and changes in optical ef iency show up in the denominator in the dollars-per-watt calculation.

${ }^{4}$ Solar Optics Program, 3M Optics Technology Development, 3M Center Bldg. 225-2N-06, St.

Paul, MN 55144-1000.

${ }^{5}$ See note 2 above.
} 


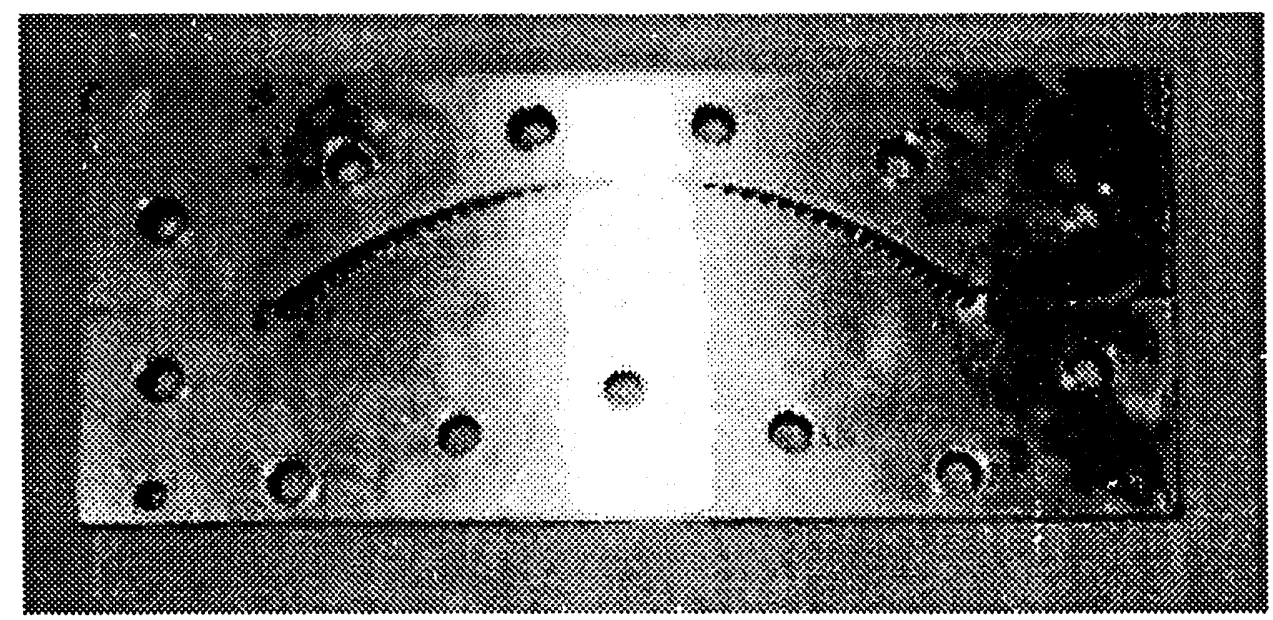

Figure 4. Die Plate for 7-inch Wide Lens

Figure 5 shows a cross section of the actual molded part. The malformation of the facets and top surface is evident. The best transmission on this lens was $71 \%$ when measured at Sandia with a 8.5:1 concentration ratio. 

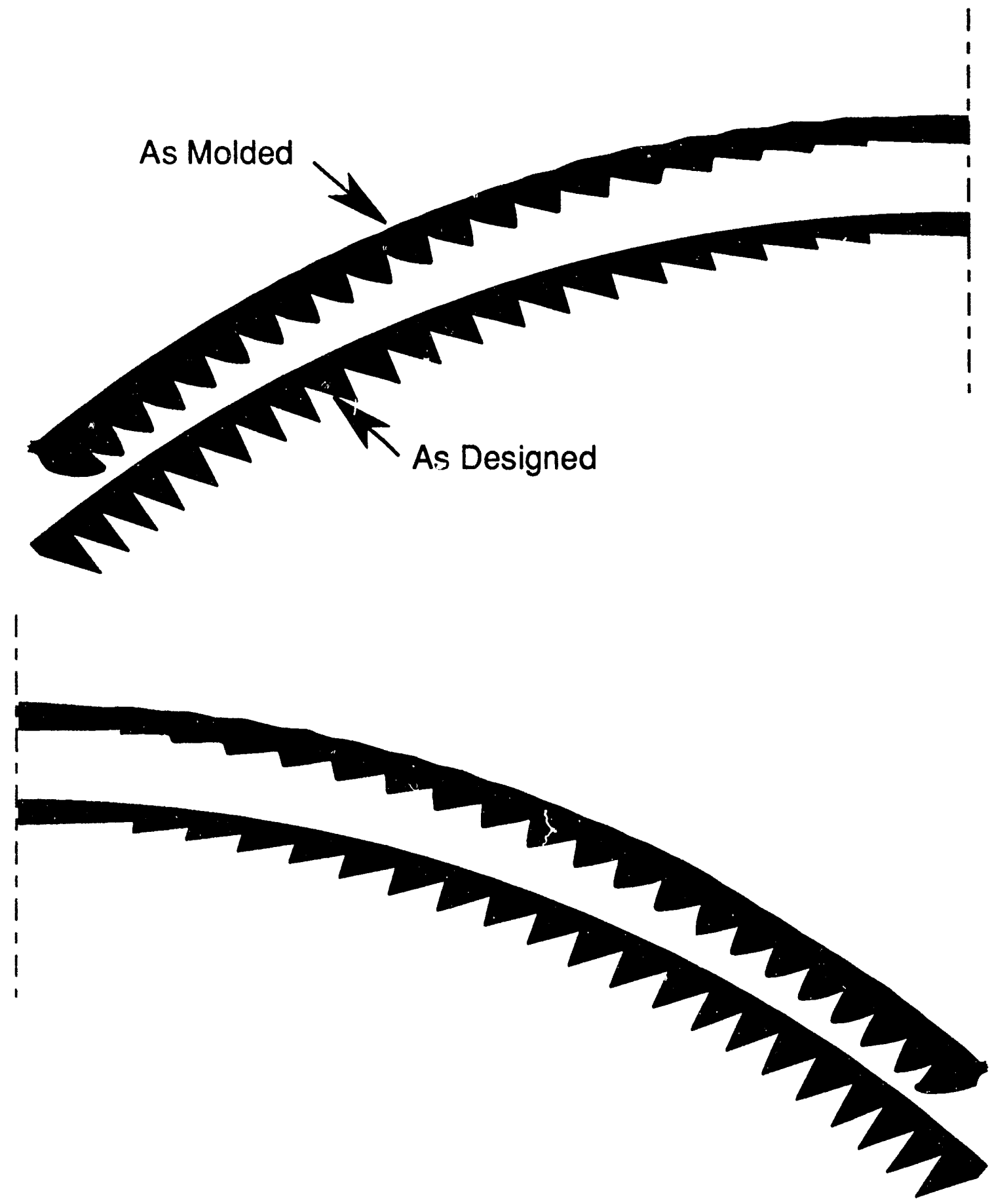

Figure 5. Cross Section of Molded 7-inch Lens 


\subsubsection{Design of 10-Inch Lens}

Because of difficulties with the original company, it was decided to move to the present extrusion company, which has had previous experience in molding similar parts for other applications. This meant a brand new die and this gave us the opportunity to re-examine the lens width in terms of optimized electricity cost. As shown in figure 6, a wider lens would be more cost-effective. A lens width of 10 inches was picked based upon the cost calculations and the practical size limit imposed by the extrusion machine (with the module sides added to the lens as planned).

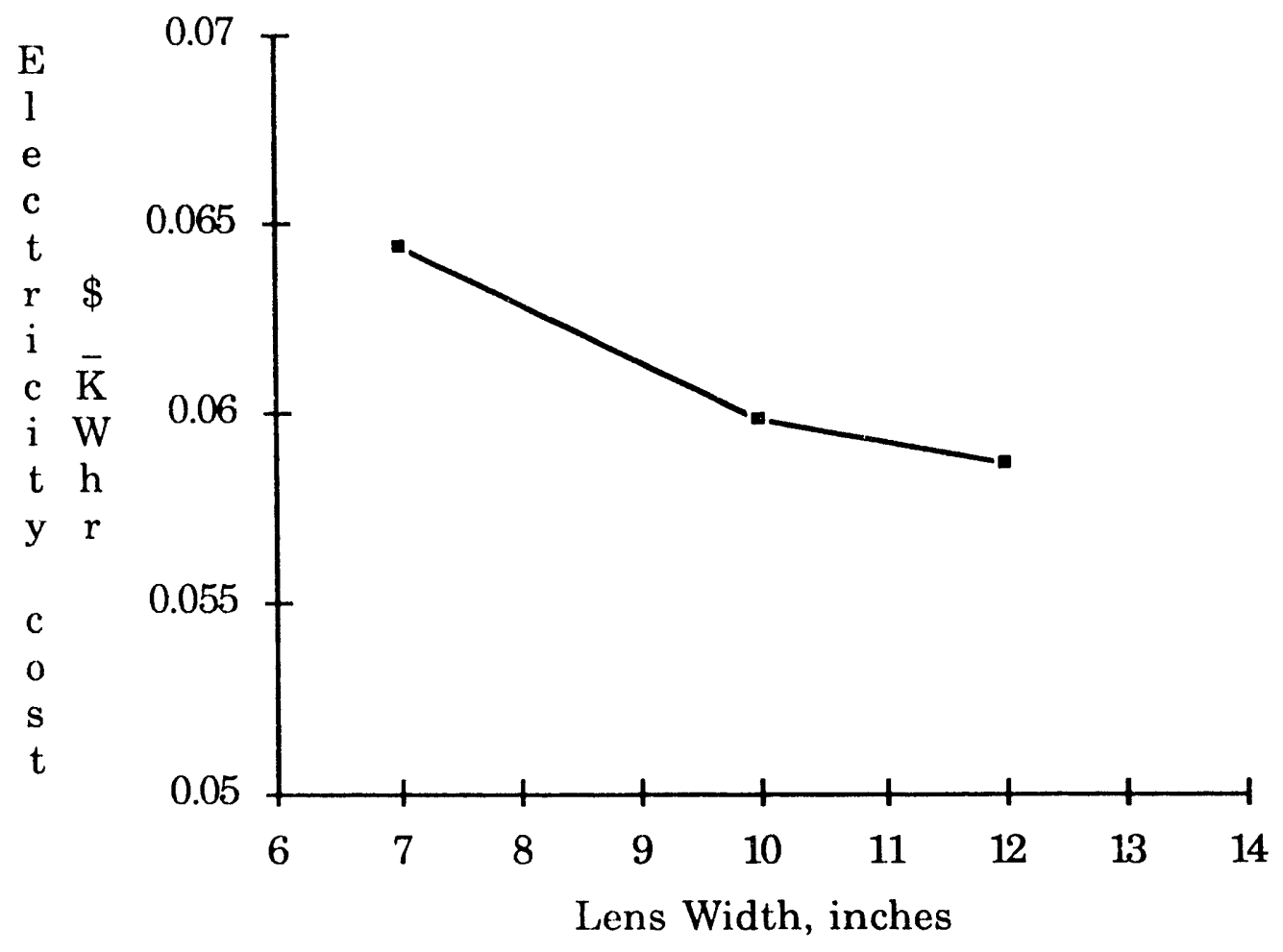

Figure 6. Cost verses Lens Size

A new 10-inch-wide line-focus lens was designed using the SEA in-house ray trace computer program. The cross section of this lens design can be seen in figure 7 and in drawing 10087 in Appendix A. A leveling of the flux profile occurs in the extruded lens because the facets, so far, have been malformed slightly in the extrusion process. Also, spreading can be accomplished by moving the cells 
closer to the lens. The lens was designed using equal volumes of plastic in each facet to facilitate the uniform distribution of the acrylic in the die, see figure 7 . The two center facets are smaller in volume than the remaining facets because the facet width is limited to $0.3 \mathrm{inch}$. An $\mathrm{f}$-number of 0.6 was possible due to the curved top surface of the lens giving a vertical height from the side of the lens to the focal line of 6 inches. The cell is moved 0.35 inch closer to the lens during ray tracing to simulate the uniform flux distribution obtained in the actual molded part. Facet size is determined by ininimizing the losses caused by malformation of the facets and losses at the root radii. Malformation increases with larger facets, while losses due to root radii decrease.

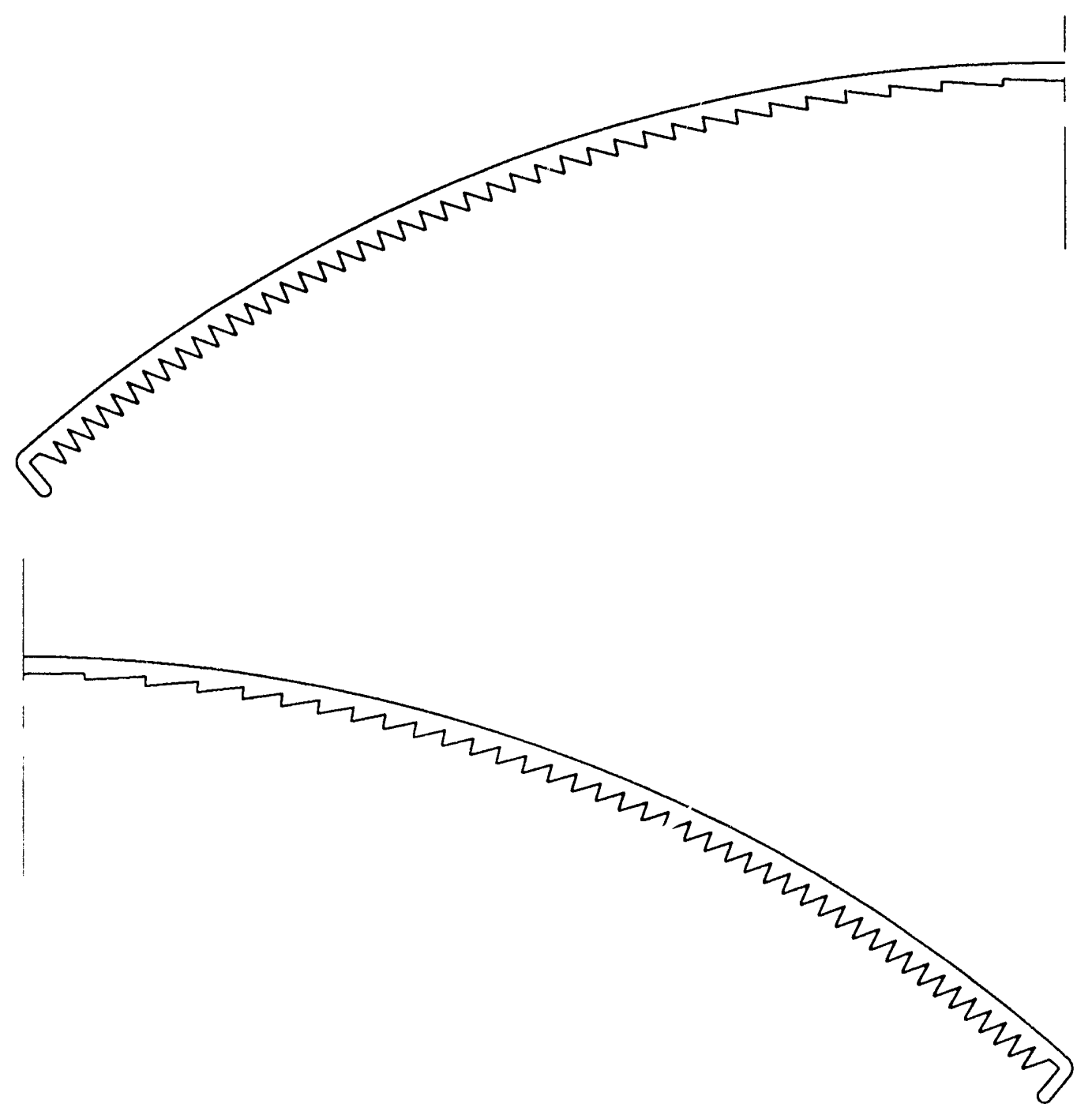

Figure 7. Cross Section of 10-inch Wide Lens Mod 20.4 
The ray trace program was used to calculate a maximum lens transmission of 90\% for lens Mod 20.4. (This is the lens transmission to the cell and does not include any cell : nti-reflection (AR) coating losses or grid line obscuration.) The reflective inside surfaces of the module act as a secondary optical element for improved on- and off-track performance, see figure 8 . Calculated off-track performance in the east-west direction can be seen in figure 9. Calculated performance with different north-south apparent sun declination angles (apparent sun angle) can be seen in figure 10.

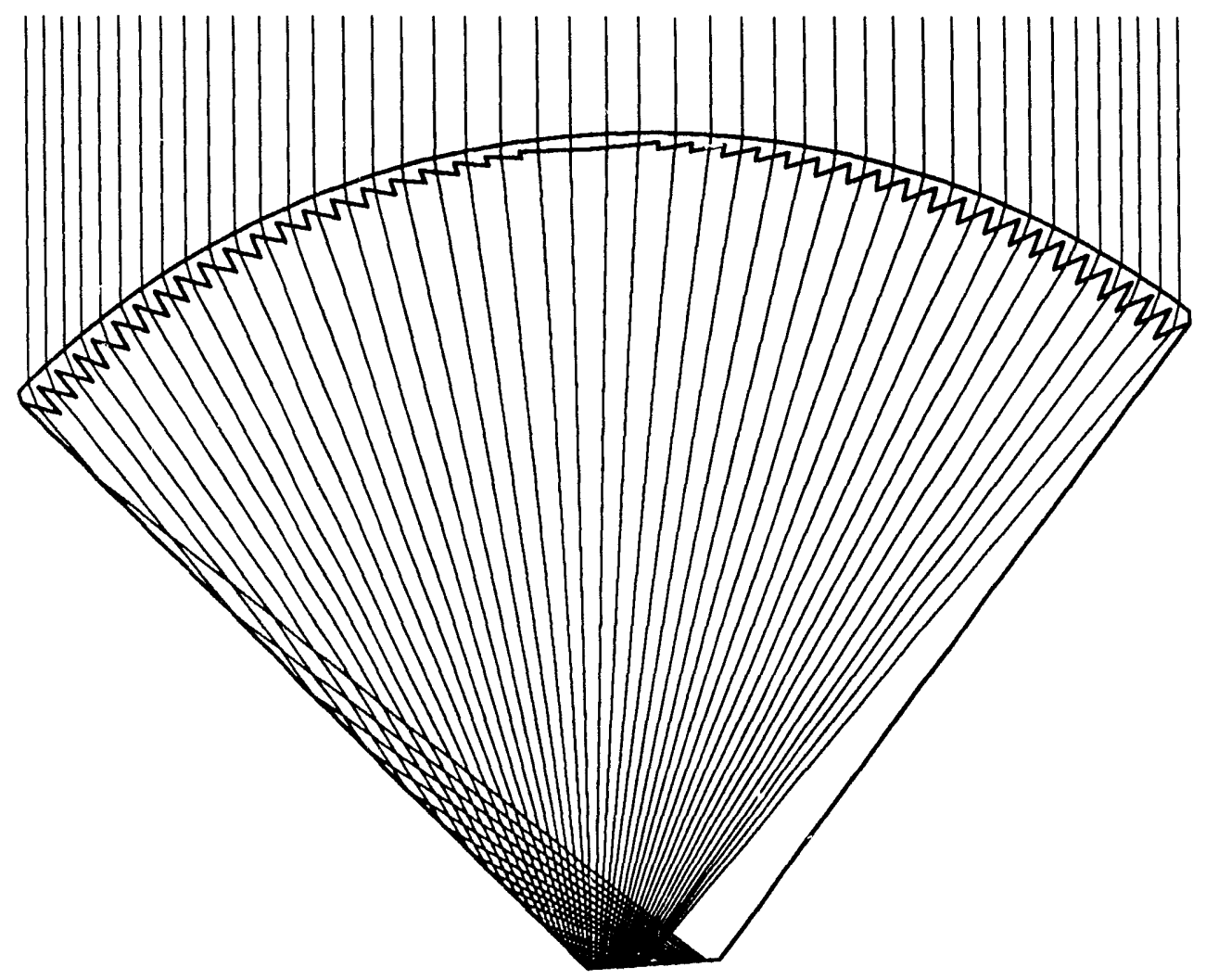

Figure 8. Off-Track Ray Trace 


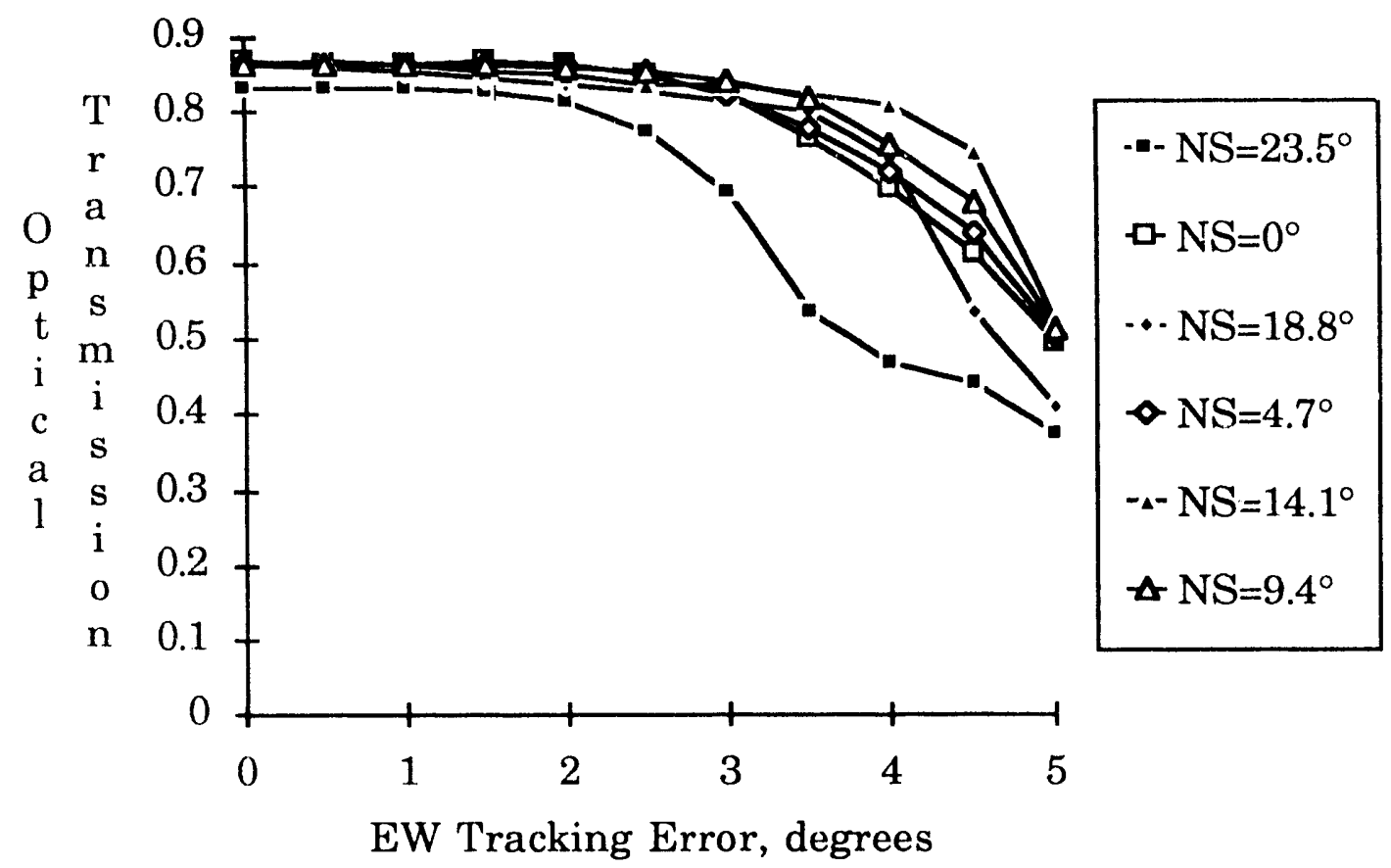

Figure 9. Calculated Off-Track Performance in the East-West Direction

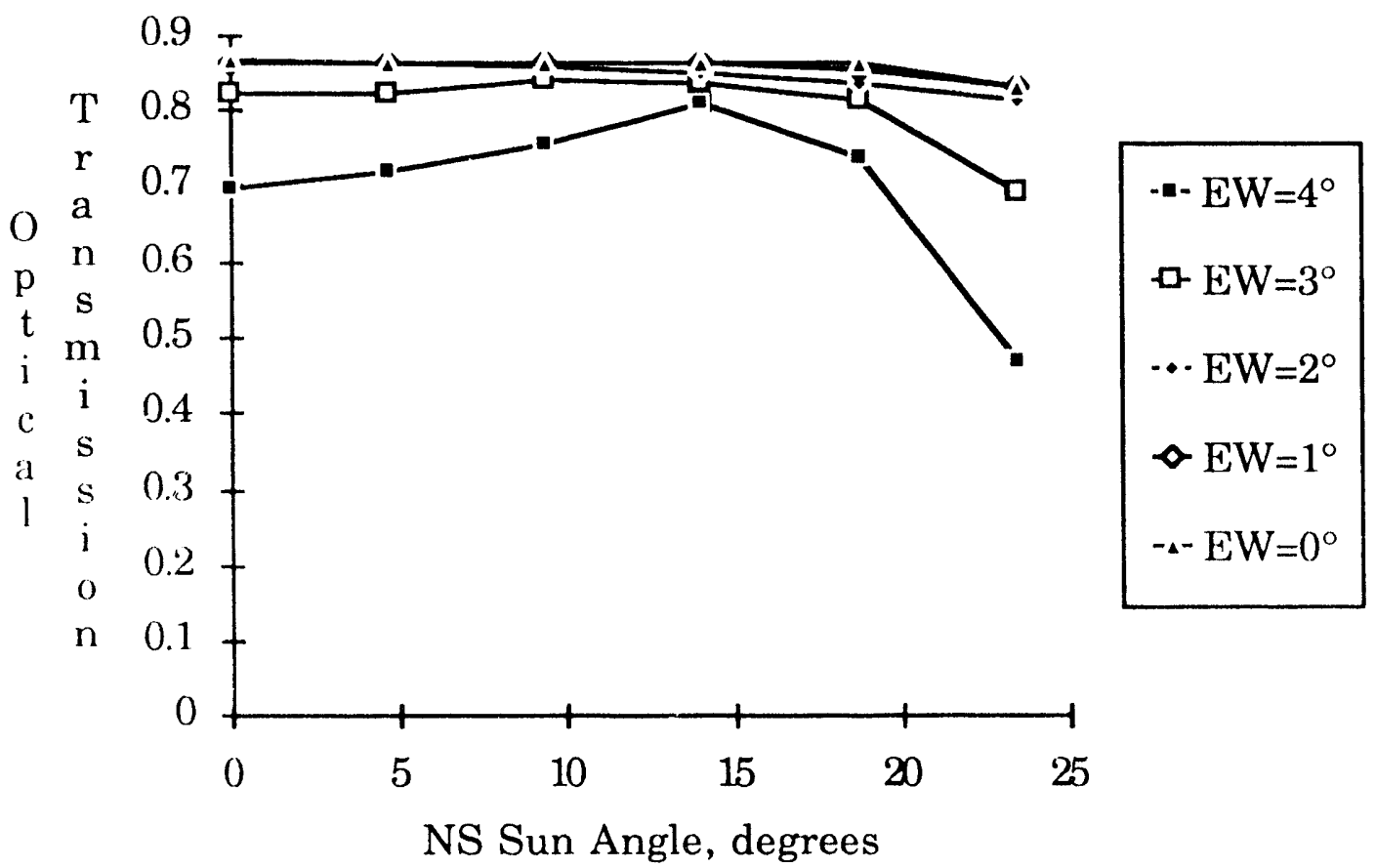

Figure 10. Calculated Performance with Different Apparent Sun Angles 
For the SEA 10X single-axis, tracking concentrator array, the north-south apparent sun declination angle varies from $+23.44^{\circ}$ in mid-summer to $-23.44^{\circ}$ in mid-winter. The effective focal length of the lens gets shorter with larger northsouth sun angles. Also, the shortening is more pronounced for rays that are refracted through greater angles at the edges of the lens. To prevent cell shading during these north-south sun shifts, the lens is made longer than the receiver.

The sun dwells near the higher values of absolute north-south sun angles during summer and winter and races through the zero north-south sun angle in fall and spring. The north-south sun angle approximates a sine curve, see figure 11 . The average north-south sun angle is approximately $15^{\circ}$.

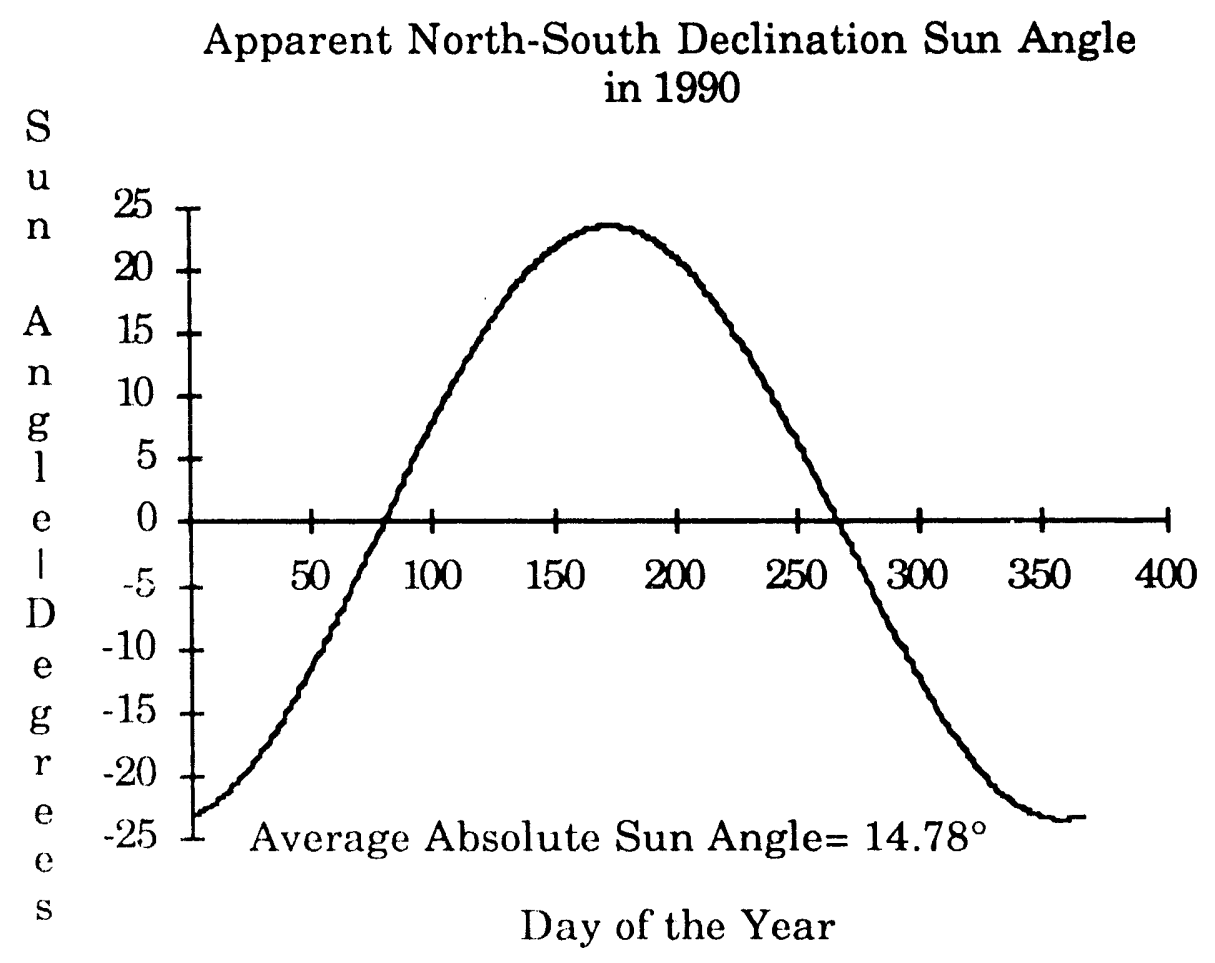

Figure 11. Apparent North-South Declination Sun Angle 6

${ }^{6}$ The Astronomical Almanac for 1990, pp C4-C19, (U.S. Government Printing Office, Washington I).C., 199(0) 
To properly analyze the performance of any concentrator optical system, the optical transmission must be averaged over the year. This can be done by integrating, over the year, the optical transmission at a specific north-south sun angle times the duration of the sun at that angle. Expected average off-track angle and expected average geometric inaccuracy of cell placement should be factored in too. An optical system should be designed for best integrated yearly performance.

\subsubsection{Molding of 10-Inch Lens}

Many trial moldings were completed. Three major modifications, and many small modifications to the original die, were done to improve transmission. These proprietary modifications were to the area of the lens die upstream from the final opening and were designed to improve material flow. No modifications were done to the actual facet form. The acrylic lens material shrinks approximately $20 \%$ after exiting the die, see figure 12. It also pulls back (features that are long and thin become short and fat), so that the facets are reduced in aspect ratio. Figure 13 shows how a typical die opening is made to achieve the desired facet form. Cross sections of the actual molded parts and optical transmissions are given in Section 2.3 , Lens Results. 


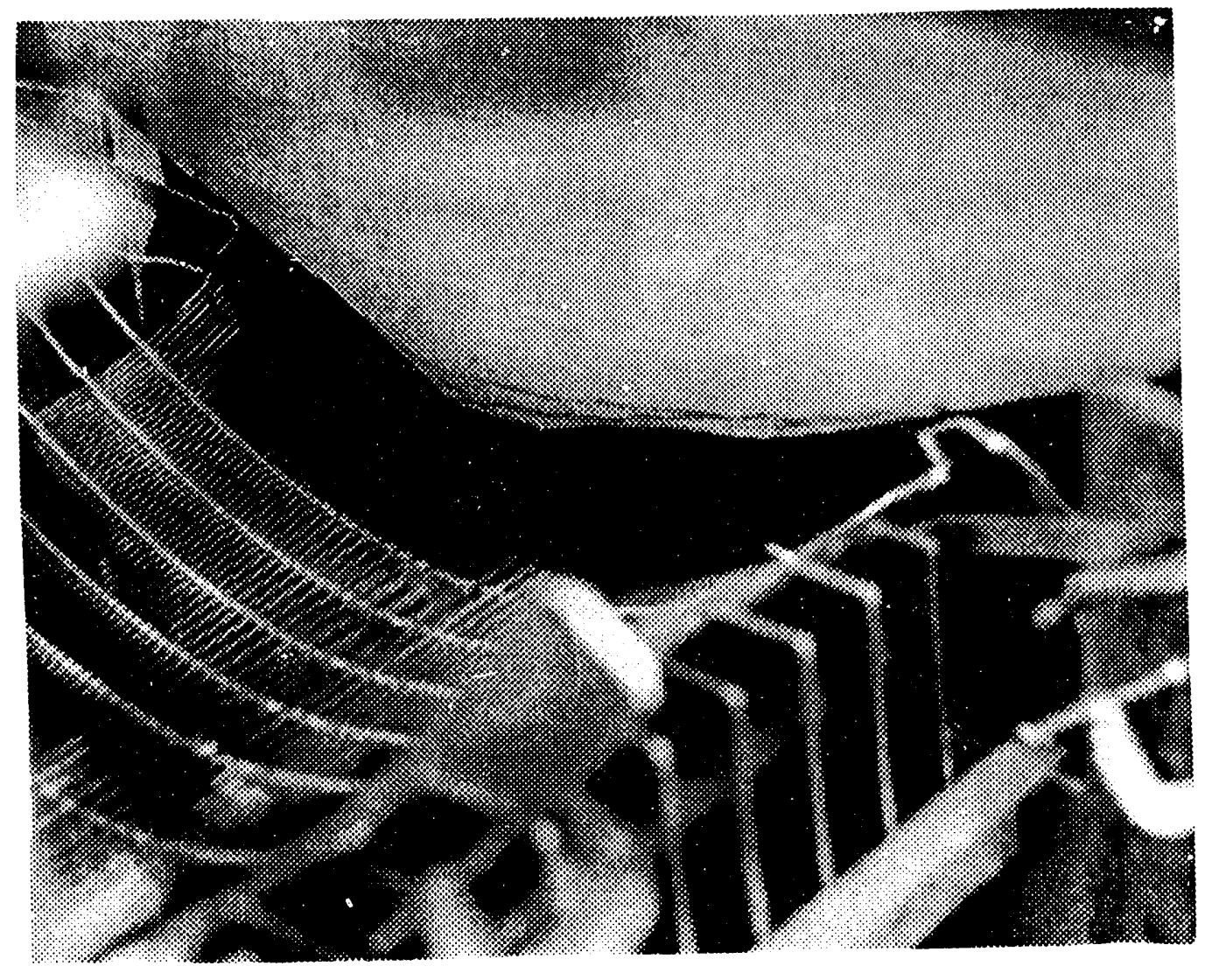

Figure 12. Photo of Extrusion Process 


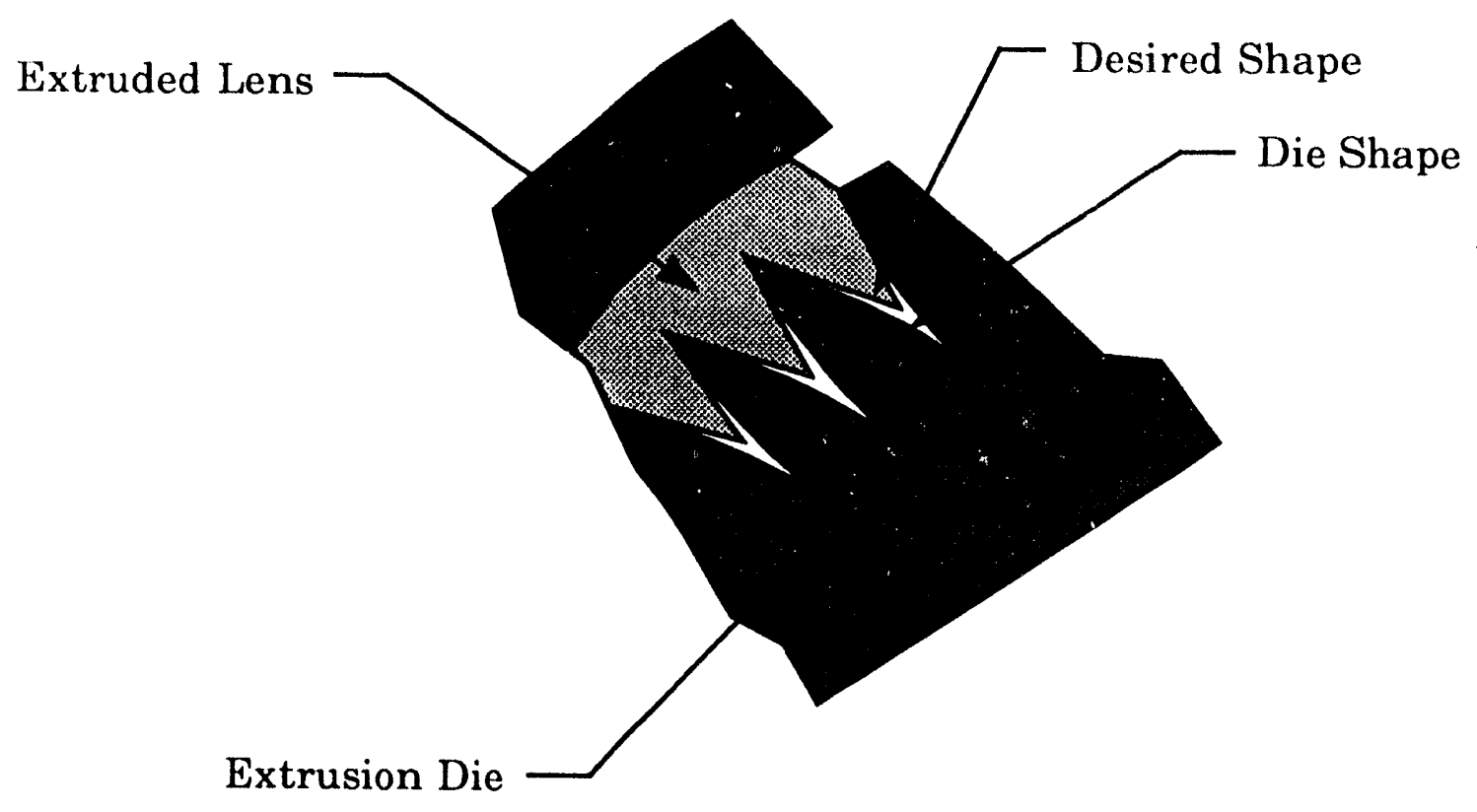

Figure 13. Die Shape for Proper Fresnel Shape

'The performance of the first extruded lenses was very encouraging. Therefore, it was decided that the fall-back paths of adopting a $3 \mathrm{M}$ lens to the design or to develop a post-extrusion forming machine were not needed. Before this decision was made, a preliminary design for a post-extrusion machine was done. This machine involved a large roller with the female Fresnel pattern on it and a series of flat rollers and air pressure to force the still-soft acrylic against the patterned roller. These types of machines have been tried in the past with limited success. One major problem is that the lens must be extruded in a flat configuration and then curved in a post forming operation. Another major problem is the tracking of the extrusion with the patterned roller. SEA developed a proprietary design that solves both these problems, but it was decided to shelve the design because of the excellent progress being achieved with the extrusion process. 


\subsubsection{Hail Tests}

'To obtain some preliminary data on the ability of the lens to survive hail, a simple of the 7-inch wide lens was subjected to the Sandia ice ball test. Simulated hail, ice balls, of 0.5-, 0.75- and 1-inch diameter were impacted onto a 7-inch wide lens with sides and ends installed. Impacts were made at various locations down the length of the lens. Because the end plates were not fabricated per the final design, Sandia did not strike the lens near the ends.

\subsection{Results}

\subsubsection{Molding}

Each modification to the 10-inch lens die yielded a slightly better form, see figure 14. The profiles are described below:

Mod 1 is the original test after some minor modifications to the die. The top surface has a series of bumps that are more pronounced near the center. The facet surfaces are concave. (The root radii are smaller than shown on figure 14 due to the reproduction process.) The facets show evidence of lack of material flow. The transmission of this lens was approximately $70 \%$ at a concentration ratio of approximately 8.91:1 when tested at Sandia.

Mod 2 was molded after the upstream section of the die was modified to force the material toward the facets and away from the top surface. The profile shows a much improved top surface, but the facets near the center are now convex indicating an excessive flow in that area. The transmission of this lens was approximately $73 \%$ at a concentration ratio of approximately $8.91: 1$ when tested at Sandia.

Mod 3 shows the results of modification to the die to restrict the flow in the center facets. The restriction has gone too far, as the facets are now concave. Also, an additional lip has been added to the lens edge to aid in assembly. The transmission of this lens was approximately $76 \%$ at a concentration ratio of approximately 8.91:1 when tested at Sandia. 


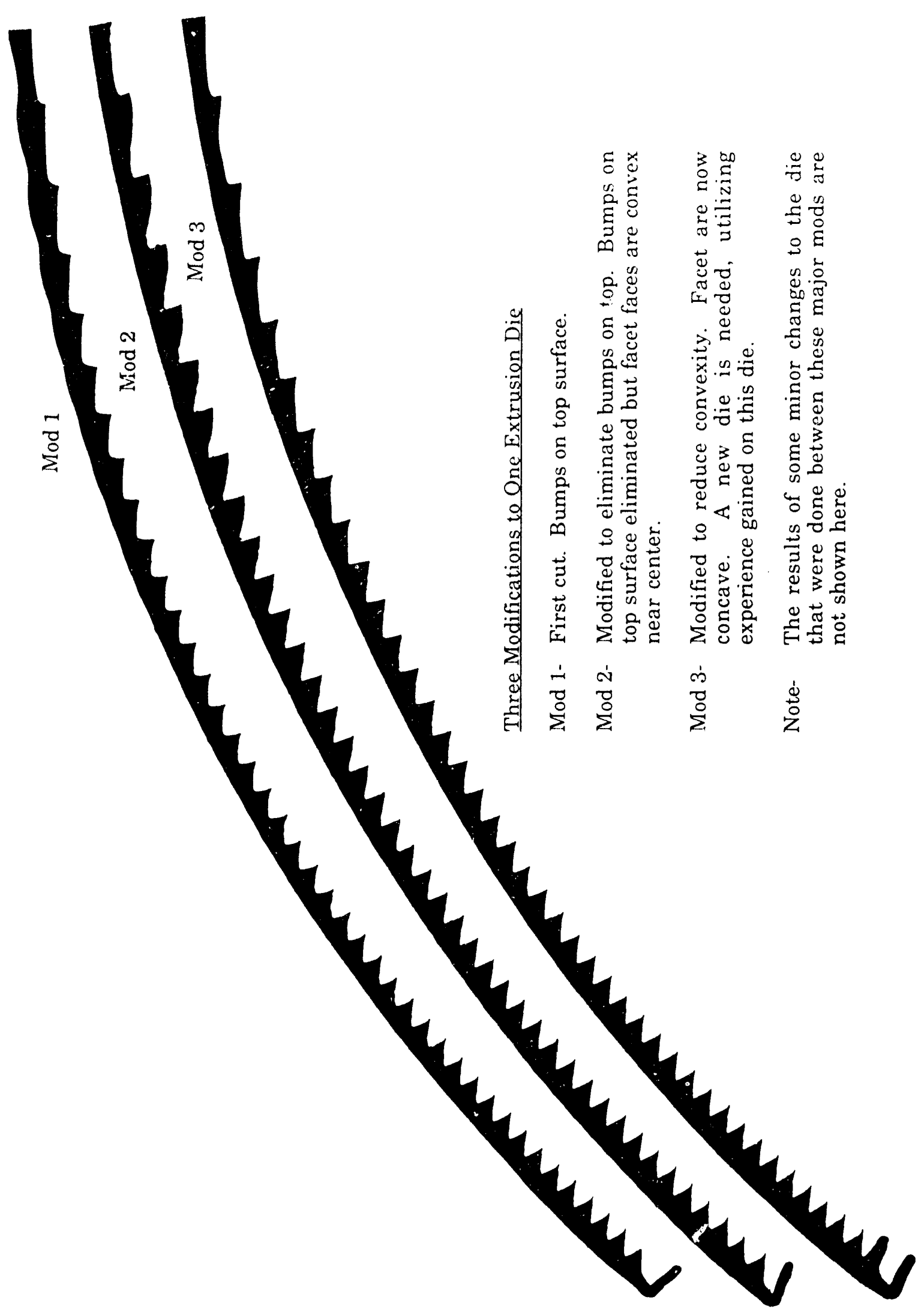

Figure 14. Results of Development of the Extrusion Die 
The modifications to the lens die are generally irreversible, that is, material is removed that is not easily replaced. After the mod 3 test, a new die was needed for further significant improvement. This was deemed beyond the scope of this contract, as the transmission goal was met and the money allotted to lens development was spent.

Further improvement in transmission can be accomplished by polishing and hardening the die. The process of cutting the die leaves a series of microscopic ridges that are replicated in the lens. These ridges diffract the light and cause significant losses. Also, there can be further significant improvement in facet form with a new die. The experience gained during this contract can be utilized to produce a die that will mold lenses with over $80 \%$ transmission.

\subsubsection{Hail Tests}

The results of the hail tests indicated that the 7-inch lens passed; however, there was not a lot of reserve. There were no breaks in the lens from the 0.5 -inch diameter and 0.75-inch diameter hail stones, but the 1-inch diameter hail stones knocked two holes in the center of the lens. However, the kinetic energy of the 1inch balls was above the specification for these balls at terminal velocity. The thin center portion (less than design thickness) of the lens is the weakest place. It is expected that the lens with the proper center section thickness would survive a 1inch hail ball impact at terminal velocity. The test results imply that the 10 -inch lens should be able to survive the 1-inch hail impacts. 


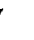




\subsection{Receiver Development}

\subsection{Objectives}

A second objective was to develop a PV receiver for use in the 10X module. Initial design work had been done but no hardware had been produced. It was necessary to verify the design. Four, 1-foot-long receiver segments were to be produced as deliverables, which were subjected to the Sandia Qualification Tests. ${ }^{7}$

The SEA in-house finite-element heat-transfer program was used to design a costoptimized, extruded-aluminum heat sink. Prototypes were built and tested to verify the computer program. The results of testing were used to modify the program for more accurate calculations and cost optimization. Two heat sinks were to be delivered to Sandia.

A cell string was designed. This cell string was complete with cells, leads, diodes, output connectors, and diode leads. The number of cells was limited to those that fit onto a 1-foot-long receiver section. The cell strings were attached to heat sinks to form the deliverable receiver sections. The adhesive bonding system envisioned for production was used.

\subsection{Component Development}

\subsubsection{Heat Sink}

\subsubsection{Heat Sink Design}

The heat sink was designed using an in-house finite-element heat-transfer computer program. 'The program works by a system of node points, or elements, which are connected to each other by conduction paths. The heat source is the solar input, reduced by the lens transmission and by the cell's efficiency in accordance with the following formula:

${ }^{7}$ R. S. Barlow, E. H. Richards, Qualification Tests for Photovoltaic Concentrator Cell Assemblies and Modules: SAND86-2743•UC-275 (Albuquerque: Sandia National Laboratories, 1988 ). 
$($ Heat in $)=($ Solar Insolation) X (Lens Transmission) X $(1$ - Cell Efficiency).

Initial temperatures are first assumed and then adjusted until io net heat flow occurs at each element (heat in equals heat out). The convection heat-transfer coefficient to the surrounding air is determined by the Nusselt number, which is determined by the Prandtl and Reynolds numbers. ${ }^{8}$ The average temperature of the air in the boundary layer, the free stream velocity, and the distance from the leading edge all must be known to accurately calculate the convection heattransfer coefficient. An average boundary layer air temperature is first assumed. It is then recalculated periodically during the running of the program based on the ambient temperature and the temperature of the heat sink. Radiation heat transfer is an important factor and was taken into account by the program. A coefficient of emissivity of 0.8 , corresponding to a black anodized surface, was used.

\section{Extruded Heat Sink}

An extruded aluminum heat sink with four continuous fins was originally planned, see figure 15. Quotes from several aluminum extrusion houses were obtained. The cost was found to be excessive for two reasons: First, the minimum thickness possible was on the order of 0.080 to 0.100 inch. Second, the cost per pound was more than for other forms of aluminum. The heat-transfer program indicated that heat dissipation from the cell was limited by convection area and not by conduction through the fins. The minimum thickness possible for an extruded heat sink was far more than what was needed.

${ }^{8}$ J.P. Holman, Heat Transfer, p. 111, (McGraw-Hill Book Company, 1963). 


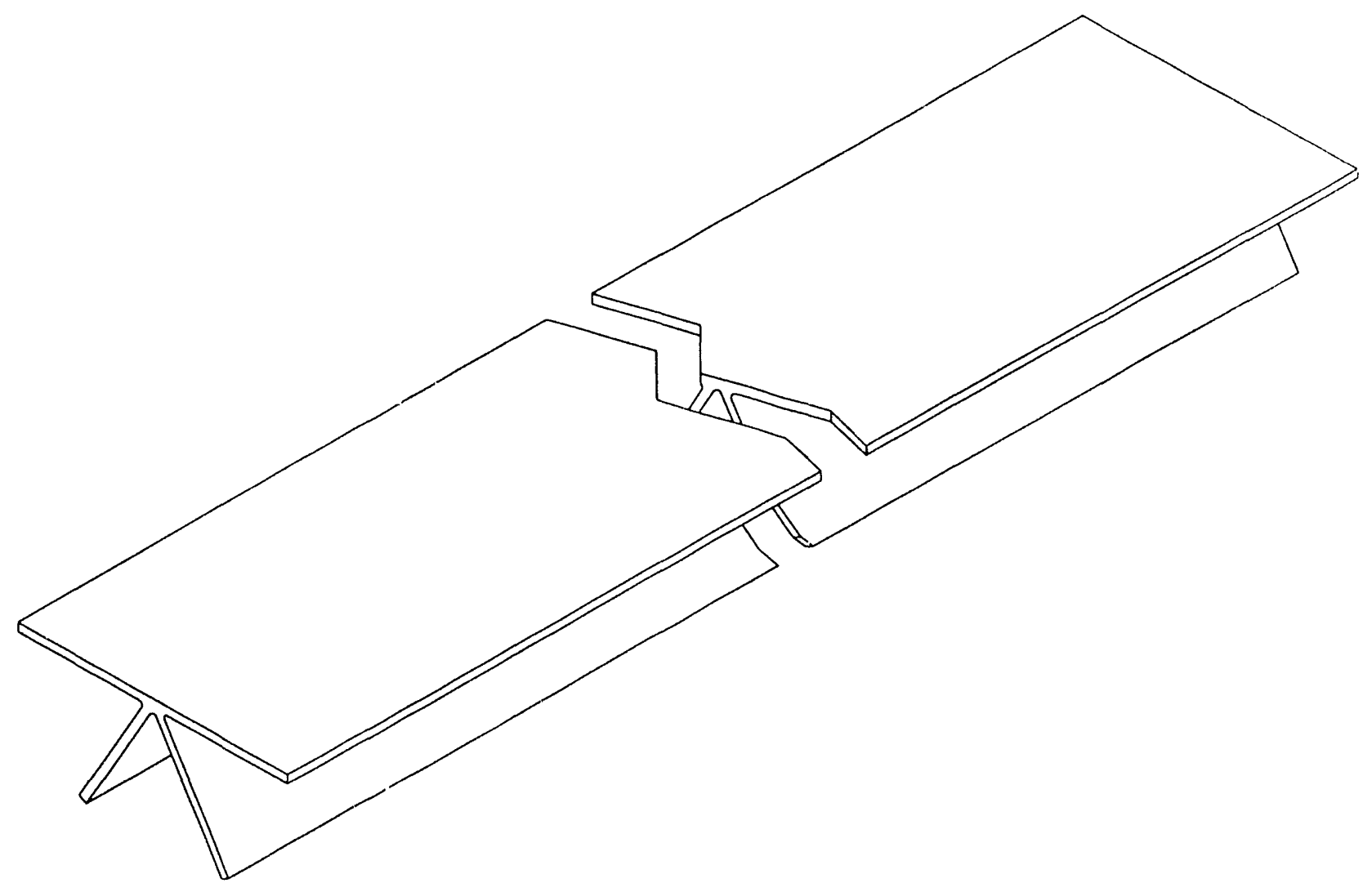

Figure 15. Original Extruded Aluminum Heat Sink

\section{Sheet Metal Heat Sink}

A sheet aluminum heat sink was then designed as shown in figure 16. The cost of the basic material was approximately two-thirds the cost of the extruded material and the minimum thickness was only limited by structural considerations. The sheet metal heat sink has a series of slits at 1-inch intervals, and alternate fins are bent down to a $45^{\circ}$ angle (segmented fins). This improves heat convection by reducing the average boundary layer thickness. 


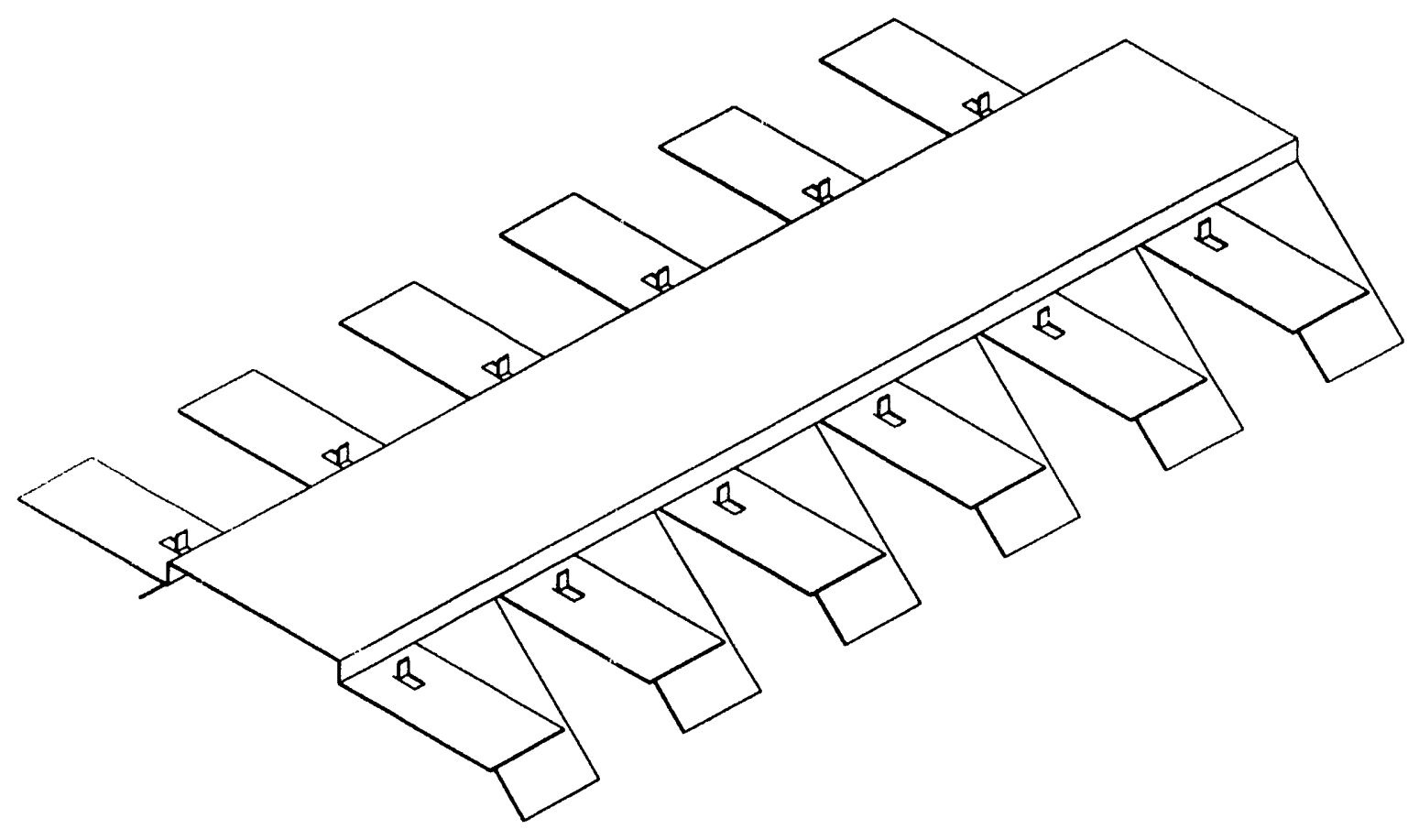

Figure 16. Sheet Aluminum Heat Sink

The sheet aluminum heat sink design was analyzed by calculating electricity cost for different dimensions. The cost of the aluminum in the heat sink is significant and must be traded off against the performance. First, the cell junction temperature was calculated using the finite-element heat-transfer computer program. The cell performance was then reduced to correspond to this temperature and system output calculated. System cost was then calculated for the particular heat sink design. A set of curves as shown in figure 17 results. The curves indicate that at a given heat sink thickness, a minimum cost occurs at a certain fin length. They also indicate that minimum cost will occur using very thin heat sinks. The minimum heat sink thickness is limited by structural reasons. 


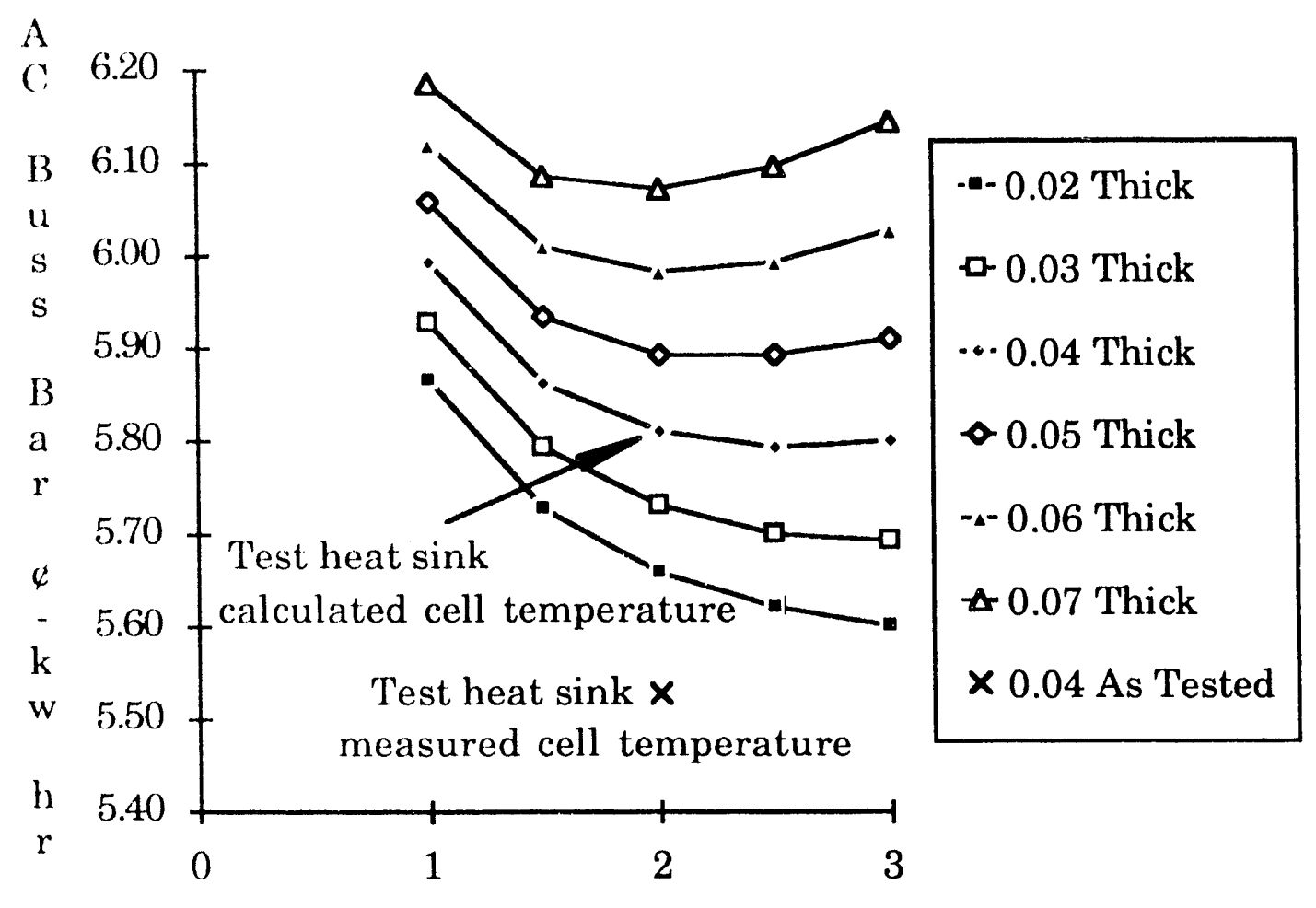

Fin Length, inches

Figure 17. Electricity Cost Calculation for Different Heat Sinks

The results from the computer program were tested by building sample heat sinks, mounting cells, and measuring the temperatures outdoors. The computer program was then re-run using the physical conditions experienced during the tests and the results were compared. In every case, the measured temperatures were lower than the calculated temperatures. (The results of the heat sink tests are presented in Section 4.2 , Receiver Results.)

The heat-transfer computer program was modified by adding two correction factors, one to reduce the heat input to the cell, and the other to increase the convection heat transfer. These factors were adjusted until the heat-transfer computer program tracked the empirical data within $5^{\circ} \mathrm{C}$. 


\subsubsection{Heat Sink Manufacturing}

Two sets of heat sink test segments were produced; the first set was 0.040 inch thick with 2-inch-long fins, and the second set was 0.032 inch thick with 2-inchlong fins, see drawings 10096 and 10100 in Appendix A. The prototype sheet aluminum heat sinks used in this program were manufactured by using a numerically controlled punch press and a series of sheet metal breaks. In production, they would be formed from roll stock with the use of a series forming rollers and transfer punches. A turn-key system, using this technique and capable of producing $200 \mathrm{MW}$ 's worth of heat sinks per year, can be purchased for about $\$ 400,000$.

The aluminum material used to make the heat sinks was 5052-H32. Materials that have higher heat transfer coefficients and/or give better standoff when anodized are available, but these aluminums are speciality metals and cost a premium. 5052-H32 is readily available, low cost, and easily formed using punching and bending. It is the most cost-effective aluminum to use for the heat sink.

The heat sinks were anodized using the SEA standard anodizing specification, 10015, which can be seen in Appendix A. There is a great deal of variation between anodizing vendors, who must be qualified by having them submit samples for evaluation. Several local vendors were evaluated by having them anodize 4-inch square coupons, see table 1 . One-inch diameter copper disks were then bonded to the coupons using the standard wet RTV adhesive method. Each coupon was then subjected to a highpot test. The results of these tests can be seen in table 1. Finisher's was chosen for anodizing the heat sinks on the basis of performance and cost. In production, the anodizing would be moved in-house to reduce cost and improve QAQC. 
Table 1. Results of Anodizing Vendor Qualification Testing

\begin{tabular}{|l|l|l|l|l|}
\hline Company & Sample \# & Alloy & Primer & $\begin{array}{l}\text { Break Down } \\
\text { Voltage }\end{array}$ \\
\hline \hline Finisher's Inc. & 1 & $5052-\mathrm{H} 32$ & No & 2300 \\
\hline Finisher's Inc. & 2 & $5052-\mathrm{H} 32$ & No & 2250 \\
\hline Finisher's Inc. & 3 & $5052-\mathrm{H} 32$ & No & 2350 \\
\hline Finisher's Inc. & 4 & $5052-\mathrm{H} 32$ & No & 2250 \\
\hline Finisher's Inc. & 5 & $5052-\mathrm{H} 32$ & No & 1950 \\
\hline Finisher's Inc. & 2 & $5052-\mathrm{H} 32$ & Yes & 3400 \\
\hline Finisher's Inc. & 3 & $5052-\mathrm{H} 32$ & Yes & 3100 \\
\hline Finisher's Inc. & 1 & $6061-\mathrm{T} 6$ & Yes & 4100 \\
\hline Finisher's Inc. & 2 & $6061-\mathrm{T} 6$ & Yes & 3400 \\
\hline Finisher's Inc. & 3 & $6061-\mathrm{T} 6$ & Yes & 3800 \\
\hline Finisher's Inc. & 4 & $6061-\mathrm{T} 6$ & Yes & 3800 \\
\hline Finisher's Inc. & 5 & $6061-\mathrm{T} 6$ & Yes & 3800 \\
\hline P.K. Selective & 1 & $5052-\mathrm{H} 32$ & No & 1950 \\
\hline P.K. Selective & 2 & $5052-\mathrm{H} 32$ & No & 1600 \\
\hline P.K. Selective & 3 & $5052-\mathrm{H} 32$ & No & 1600 \\
\hline P.K. Selective & 4 & $5052-\mathrm{H} 32$ & No & 1550 \\
\hline AA Metals & 1 & $5052-\mathrm{H} 32$ & No & 2000 \\
\hline AA Metals & 2 & $5052-\mathrm{H} 32$ & No & 1000 \\
\hline AA Metals & 3 & $5052-\mathrm{H} 32$ & No & 2200 \\
\hline AA Metals & 4 & $5052-\mathrm{H} 32$ & No & 2000 \\
\hline AA Metals & 5 & $5052-\mathrm{H} 32$ & No & 1950 \\
\hline AA Metals & 1 & $5052-\mathrm{H} 32$ & Yes & 4350 \\
\hline AA Metals & 2 & $5052-\mathrm{H} 32$ & Yes & 4500 \\
\hline Nots & & & \\
\hline
\end{tabular}

Notes:

One layer RTV 0.005 to 0.008 thick

The heat sink test sections were assembled from heat sinks and PV cells using the standard wet R'TV technique, using a single layer of RTV. (The assembly techniques are described below in Section 3.3, Assembly, Receiver Development.) This produced an RTV thickness of from 0.005 inch to 0.008 inch thick. No 
conformal coating was applied to the top of the cell. No leads or bypass diodes were installed on the heat sink test sections.

\subsubsection{Heat Sink Testing}

Ten thermocouples were mounted to the heat sink, as shown in figure 18. The thermocouples mounted to the PV cells were soldered to the cell metalization. The thermocouples mounted to the heat sink were installed by drilling a 0.025 -inch diameter hole and inserting the thermal couple bead into this hole. A heat conductive, aluminium or silver filled adhesive was then used to fill up the hole and make thermal contact between the thermal couple bead and the heat sink.

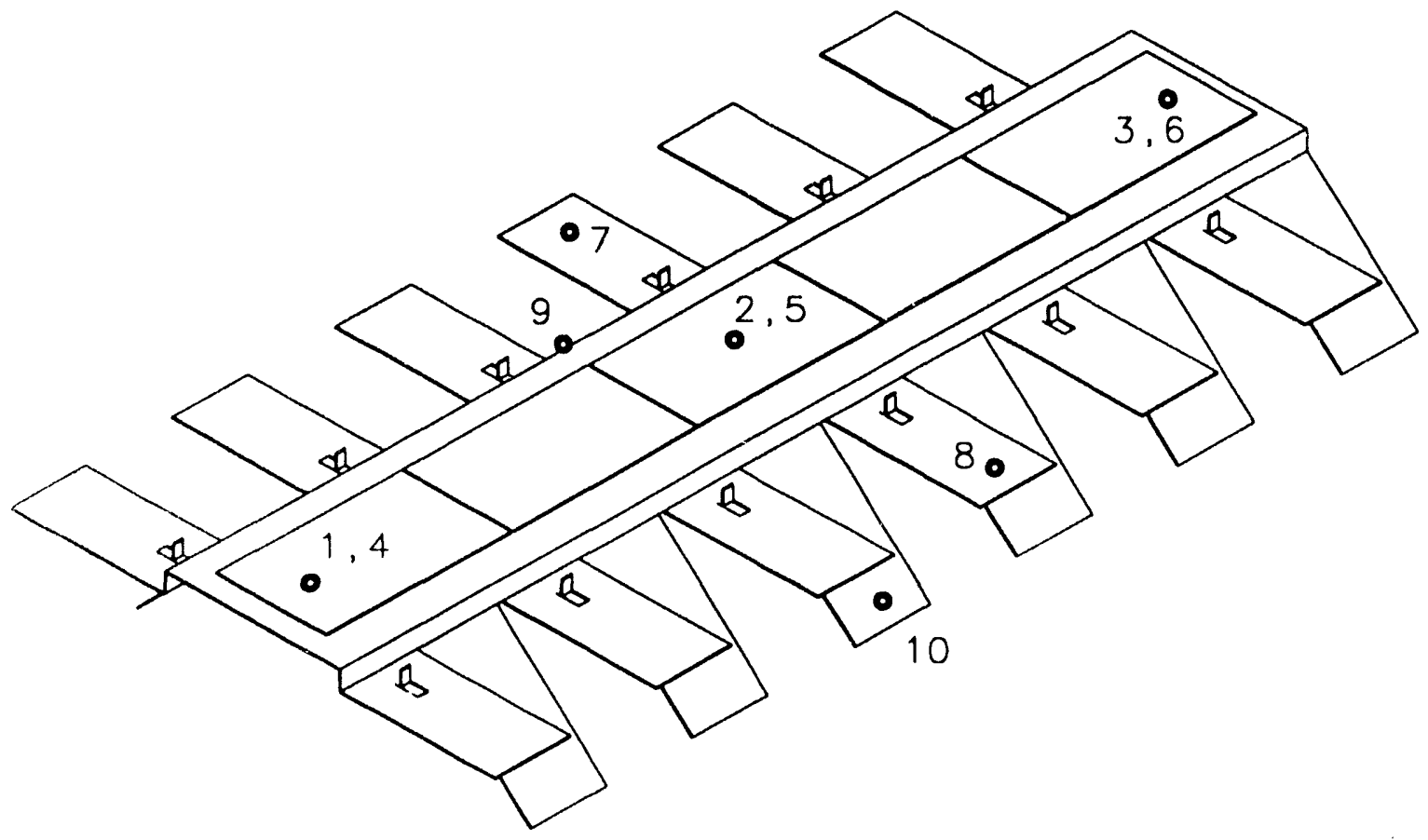

Notes:

1. TC 9 is on $45^{\circ}$ fin.

2. TC's 4,5 \& 6 are under cells on heat sink.

Figure 18. Thermocouple Placement 
'The heat sinks were tested outdoors using the thermocouples to measure temperatures; no electrical data was taken. Lenses, along with reflective sides, were attached to the heat sink. The end of the modules were blocked off to eliminate air flow through the center of the module, see figure 19. Air temperature was measured by a thermocouple located in the shade of the heat sink. Air velocity and dire viion were measured by a hand-held anemometer at the same height above-ground as the heat sink. Insolation was measured by a pyrheliometer. As described above, to compare calculated and empirical data, the heat-transfer computer program was run using the same physical conditions as experienced during the test.

The receiver sections delivered under the contract were electrically tested at Sandia. Thermocouples were installed to measure heat-sink temperature. Cell temperature was calculated based upon open-circuit voltage $\left(\mathrm{V}_{\mathrm{oc}}\right)$ and shortcircuit current $\left(\mathrm{I}_{\mathrm{sc}}\right)$ using a formula supplied by Dave King, Sandia Division $6224 .{ }^{9}$ Lens/reflective side-wall sections were supplied to Sandia to aid in the electrical testing of the receiver sections.

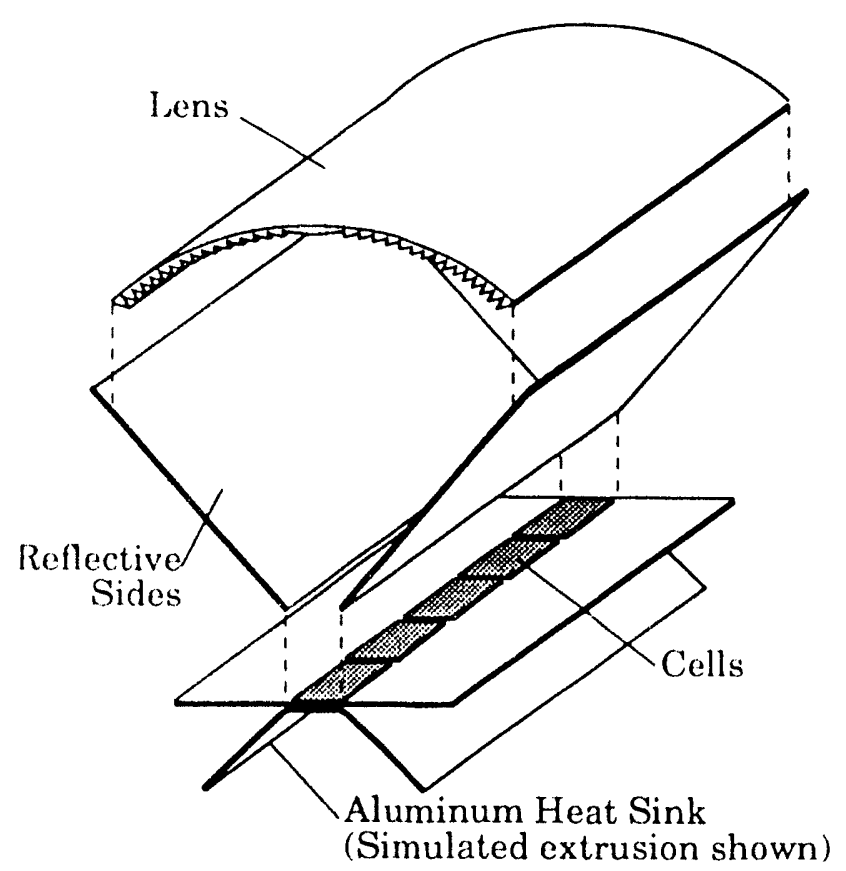

Figure 19. Heat Sink Test Setup

\footnotetext{
"Nemo dated Nov 15, 1990 to Bill Boyson, Division 6224, from D. L. King, Division 6224, Albueperque: Sandia National Laboratories. A copy of this memo in an appendix to the references in Note 15 and Note 16.
} 


\subsubsection{Heat Sink 'Test Results}

Heat sink test results, measured at SEA and Sandia, are presented below in table 2 , along with the cell temperatures as calculated by the heat-transfer computer program.

Table 2. Heat Sink Test Results

\begin{tabular}{|c|c|c|c|c|c|c|c|}
\hline$\#$ & $\begin{array}{l}\mathrm{DNI} \\
\mathrm{W} / \mathrm{m}^{2}\end{array}$ & $\begin{array}{c}\text { Wind } \\
\mathrm{m} / \mathrm{s}\end{array}$ & $\begin{array}{l}\mathrm{T}_{0} \\
{ }^{\circ} \mathrm{C}\end{array}$ & $\begin{array}{c}{ }^{{ }^{T}} \mathrm{~T}_{j}-\mathrm{T}_{0} \\
{ }^{\circ} \mathrm{C} \\
\text { Meas }\end{array}$ & $\begin{array}{l}\mathrm{T}_{\mathrm{j}}-\mathrm{T}_{0} \\
{ }^{\circ} \mathrm{C} \\
\text { Calc }\end{array}$ & $\begin{array}{c}\text { RTV } \\
\text { layers } \\
1\end{array}$ & Notes \\
\hline 1 & 900 & 2 & 23 & 21 & 372 & 1 & 0.040 thk, by TC at SEA \\
\hline 2 & 974 & 1.5 & 12 & 29 & 473 & 1 & 0.040 thk, by $V_{o c} @$ Sandia \\
\hline 3 & 981 & 1.5 & 13 & 31 & 473 & 1 & 0.040 thk, $\mathrm{T}_{\mathrm{hs}}+2^{\circ} \mathrm{C} @$ Sandia \\
\hline 4 & 981 & 3.8 & 0.3 & 32 & 393 & 2 & 0.032 thk, $\mathrm{T}_{\mathrm{hs}}+2^{\circ} \mathrm{C} @$ Sandia \\
\hline 5 & 999 & 1.9 & 4 & 32 & $46^{3}$ & 2 & 0.032 thk, $\mathrm{T}_{\mathrm{hs}}+2^{\circ} \mathrm{C} @$ Sandia \\
\hline
\end{tabular}

Notes:

\#, Test number

DNI, Direct Normal Insolation

Wind, Wind speed

$\mathrm{T}_{0}$, Ambient temperature

$\mathrm{T}_{\mathrm{j}}-\mathrm{T}_{0}$, Cell junction temperature - ambient temperature

Meas, Measured

Calc, Calculated

$\mathrm{T}_{\mathrm{hs}}$, Heat sink temperature under cell

1 Each layer 0.005- to 0.008-inch thick.

2 Unmodified program

3 Modified program

There are a number of possible explanations why the measured temperatures were lower than the calculated temperatures, two of which are: First, the heattransfer computer program did not have provision to add the segmented fin design. (This provision was added at a later date.) The segmented fins have the effect of keeping the average Reynolds number small and improving the convection heat-transfer coefficient. Second, there is evidence from the ray-trace computer program that not all of the solar spectrum reaches the cell. Infrared rays do not reach the cell because they do not have the required index of refraction through the lens and ultraviolet rays are trapped in the lens. The heat-transfer computer program does not take this into account. 


\subsubsection{Cell String}

The SEA 10X concentrator design calls for a series string of 32 cells per module, giving 16 volts nominal output. The modules are wired in parallel within the array, making the array output also 16 volts nominal. This output voltage was chosen for a number of reasons, one of which is so that 12 volt batteries can be charged by the array. This opens up a number of intermediate markets for remote applications. For large power applications, the arrays are planned to be joined end to end, and connected in series with no additional wiring. This will provide an increased output voltage, necessary for large power applications.

The modules are planned to have three bypass diodes, one diode bypassing the center 12 cells, the other two bypassing the 10 cells at each end of the receiver. This wiring circuit is the most cost effective and fault tolerant for this type of module. ${ }^{10}$ The wiring diagram for the module is shown in figure 20.

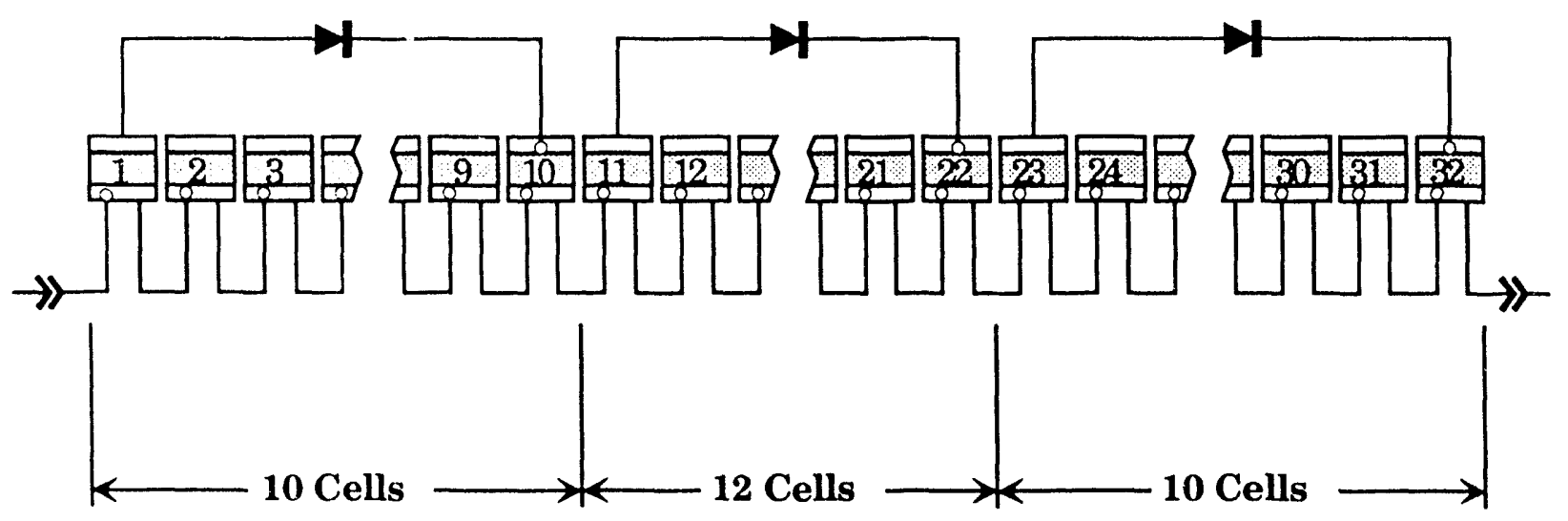

Figure 20. Module Wiring Diagram

For most of the 1-foot receiver sectiuns, only five cells were used. These cells were wired in series with one bypass diode. The receiver sec', 1 on wiring can be seen in figure 21. Two receivers used three cells each but had similar wiring.

${ }^{10}$ C.C. Gonzalez, R. G. Ross, Jr., Design of Fault-Tolerant Circuits for Photovoltaic Concentrators, SAND88-7027 (Albuqueryue: Sandia National Laboratories, 1988) 


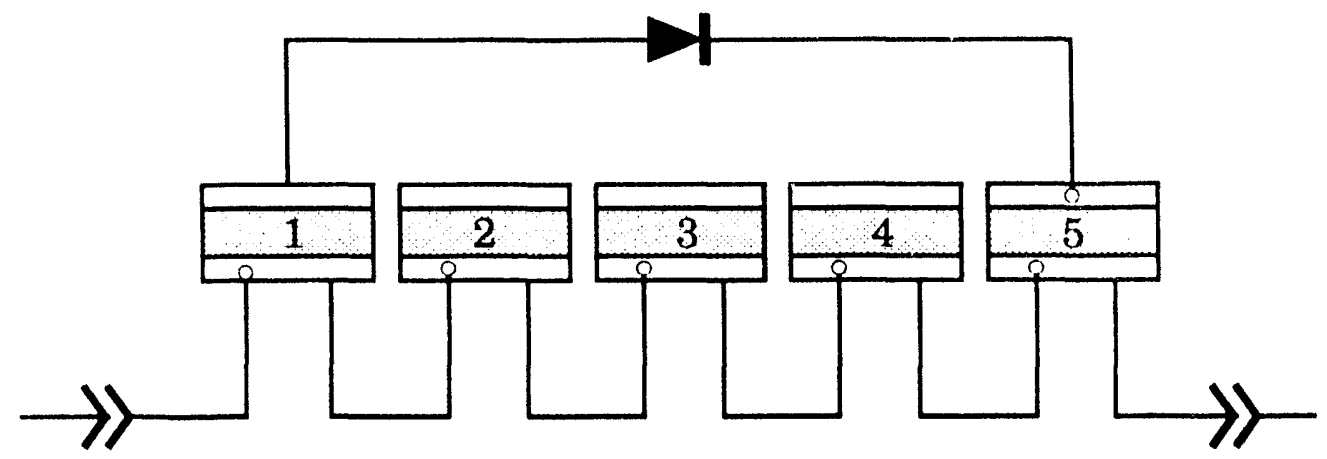

Figure 21. Receiver Section Wiring

\subsubsection{Cells}

Attempts were made to obtain one-sun cells from different manufactures. Enough cells to fabricate the required number of receiver sections were unavailable under the time and price constraints of this contract. However, samples of one-sun cells were obtained, which were tested under concentration. As shown in figure 22, two, one-sun cells were tested, one with evaporated metalization and one with screened metalization. The cell with evaporated metalization performed well at 10 suns while the cell with screened did not perform well due to low fill factor. ${ }^{11}$ (Screened metalization is about one-tenth the cost of evaporated metalization and represents a significant cost savings.) (The (.)ll manufacturers requested that their names not be published.)

Sandia provided enough linear concentrator cells to complete the contract needs. These 30X concentrator cells were originally manufactured for a Seaworld PERDA project by Applied Solar Energy Corporation (ASEC), in the City of Industry, CA in 1982, see figure 23. Twenty five cells were tested at concentration lising a flash tester. The remaining cells were tested for functionality. The average cell efficiency was $13.7 \%$ at $500 \mathrm{~mW} / \mathrm{cm}^{2}$ flux. A typical IV curve is shown in figure 23 . While not one-sun cells, they allowed us to meet the primary objectives of this contract. The cells had top side electrical busses on both sides; however, since the planned one-sun cells have a single bus, the cell-to-cell

\footnotetext{
14 ubsequent tests on cells with screened metalization designed specifically for low romentration performed well at up to 10 suns, giving fill factors of $77 \%$.
} 
interconnects were installed on only one side. The bypass diode was connected to the second set of busses.

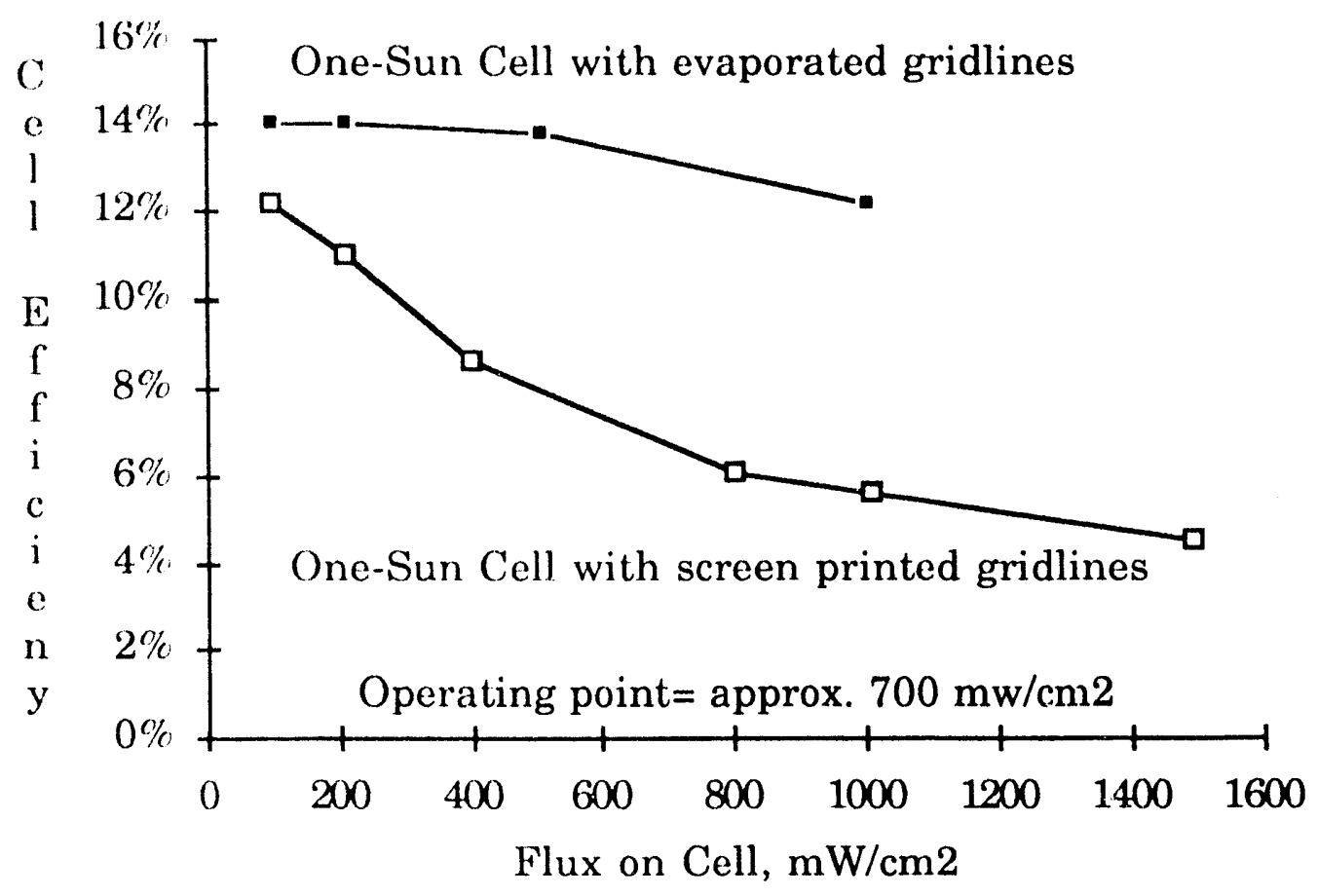

Figure 22. Performance of 'Two One-Sun Cells at Low Concentration

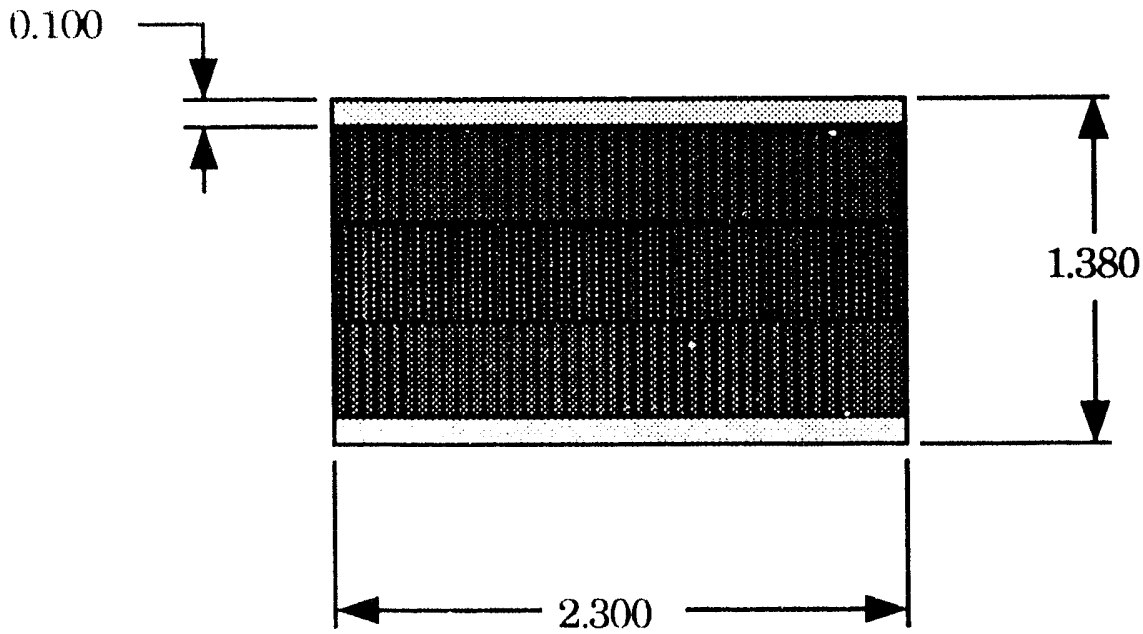

Figure 23. Sea World Cell 
Incident Energy $=500 \mathrm{~mW} / \mathrm{cm} 2$

Temperature $=250$

MAXMUM FOWER $=-1.19$ Wat $\mathrm{s}$

CURRENT is Pmax $=-2.1752$ Amps

VULATGE P Pmax $=.5465$ Volts

I-y of:ASEC Pkg. A 911 con Lnknown

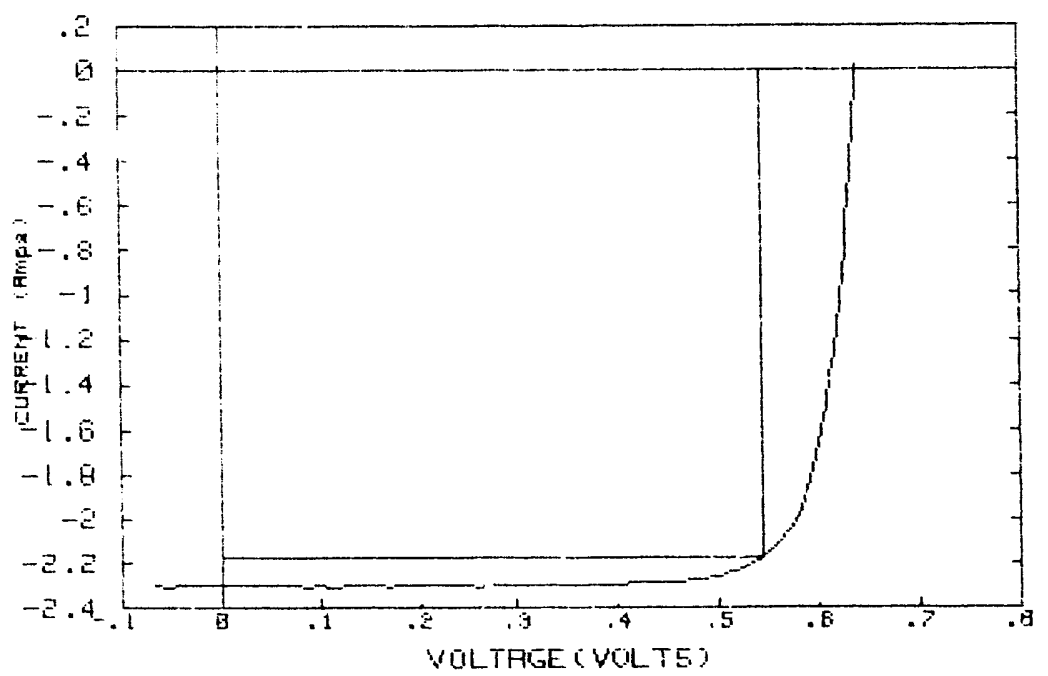

Eff $\quad 13.67 \quad(\%)$

Voc .6408 volte

Jsc $\quad 132.36 \quad \mathrm{~mA} / \mathrm{cm} 2$

FF $\quad .8059$

Figure 24. Typical IV Curve for Sea World Cell

\subsubsection{Interconnect Leads}

The cell interconnecting leads were designed to have a redundancy of small flexible fingers that are soldered to the cell for contacting, see figure 25 and Drawing 10094 in Appendix A. The many contact fingers increase the reliability of the module: the continuity of the cell string is not dependent on a few contacts. They also reduce the stress caused by differential thermal expansion between the copper fingers and the silicon cells. The leads are formed of 0.003-inch-thick copper which are plated with silver-tin-lead eutectic solder (62\% $\mathrm{Sn}, 36 \% \mathrm{~Pb}, 2 \%$ Ag). The plated solder is the only planned source of solder for joining to the cells. A silver-tin-lead eutectic solder is used to eliminate silver scavenging of the silver metalization on the cells. 


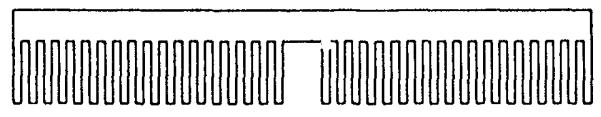

Figure 25. Cell Leads

The leads obtained for this program were plated 0.0005 inch thick and were not plated with the specified silver-tin-lead eutectic solder but with Sn 63 solder (63\% $\mathrm{Sn}, 37 \% \mathrm{~Pb}$ ). This was due to a lack of understanding of the company making the leads. Also, the thickness of solder was found to be inadequate. Additional solder was added using RMA flux core wire silver-tin-lead eutectic solder. The solder process is discussed below in Section 3.3, Assembly, Receiver Development.

Each interconnect lead joins the top metalization bus of one cell and to the bottom metalization of the next cell in series, see figure 26. No additional leads are needed. The end leads are modified to form output and input connection points. (It was planned to design output connectors for this contract, but because full-size modules were not delivered, this task was not completed.) 


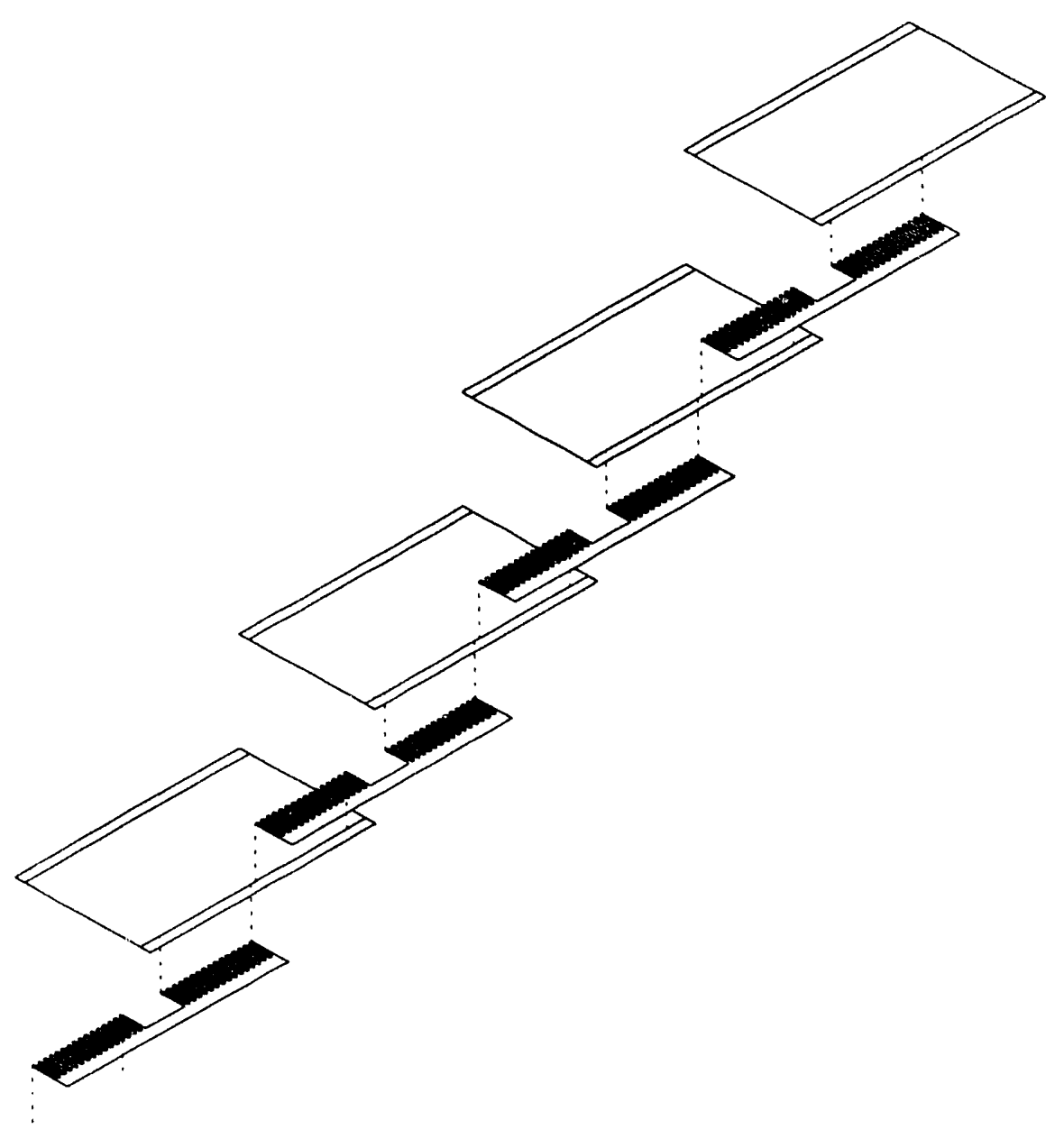

Figure 26. Cell Lead Interconnect

\subsubsection{Diodes}

Unpackaged "chip" diodes were used. It is not cost-effective to use packaged diodes, which have a great deal of cost added before reaching the module manufacturer. The packaged power-type diodes are meant for commercial applications, where they are installed using screws and hand soldering, which are not high volume techniques.

Chip diodes for power applications can be very small compared to solar cells, see figure 27. These diodes have solderable metalization on the back and aluminum metalization on the top that is designed for aluminum wire bonding in diode 
packages. Typical packaging techniques are to solder these chips to a heat spreader and connect the top contact using wire bonding.

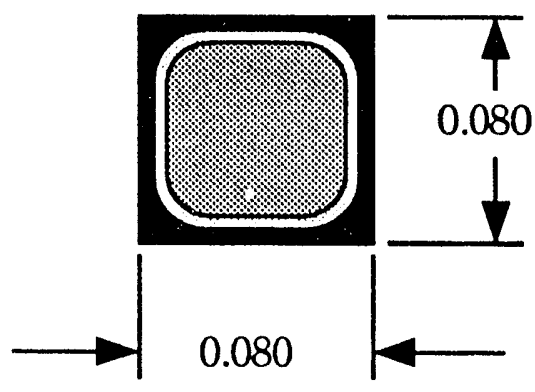

Figure 27. Unpackaged Chip Diode

The aluminum metalization for the top contact of the diode represented a problem for the use of these diodes in the module. The diode manufacturers are reluctant to change the metalization for small quantities (thousands of diodes) and wire bonding is not practical for assembling concentrator modules (because it adds another process that is unrelated to existing processes). It was felt that the diode manufacturers could be persuaded to change metalization for large quantities (millions of diodes).

It was decided to prototype the receiver by using electrically conductive, silverfilled epoxy for the top contact. The bottom contact was soldered to the electrical interconnect lead to provide the required heat sinking, see figure 28 . 


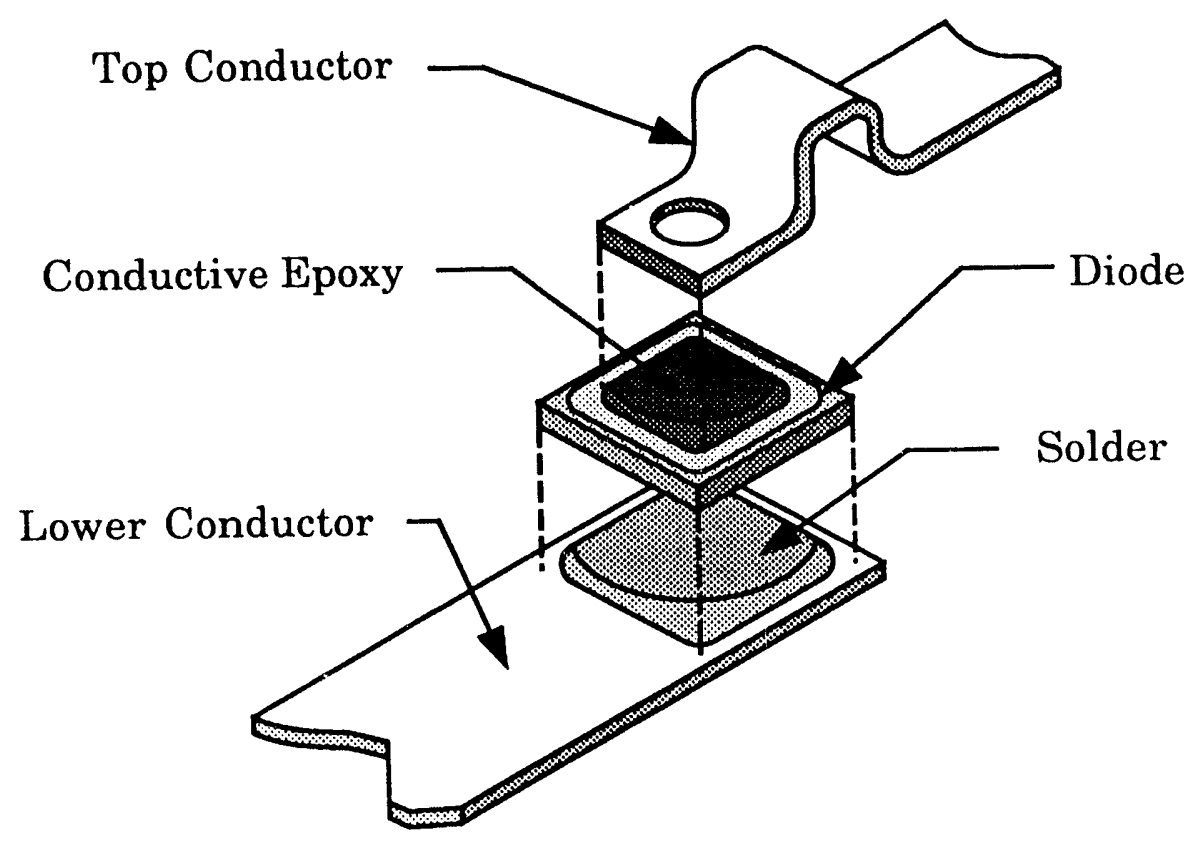

Figure 28. Prototype Diode Packaging

The packaging technique was tested by assembling three test pieces on 4-inch square, anodized aluminum sheets. An 8-amp current, twice the expected amount, was forced through the diode while the temperature and voltage drop were monitored. Reverse leakage current was also tested. In all cases, the performance exceeded the manufacturer's specification of a reverse leakage current of less than $5 \mu \mathrm{A}$ at 100 volts and a forward voltage of 0.95 volts at a current of $8 \mathrm{amps}$. The heat sinking proved adequate, with a temperature rise of less than $35^{\circ} \mathrm{C}$ above ambient at maximum forward current of 8 amps.

A separate lead system was used to connect the diodes. The cell leads were modified and soldered to the opposite side of the cell as shown in figure 29. A copper strip was used to complete the diode circuit. 


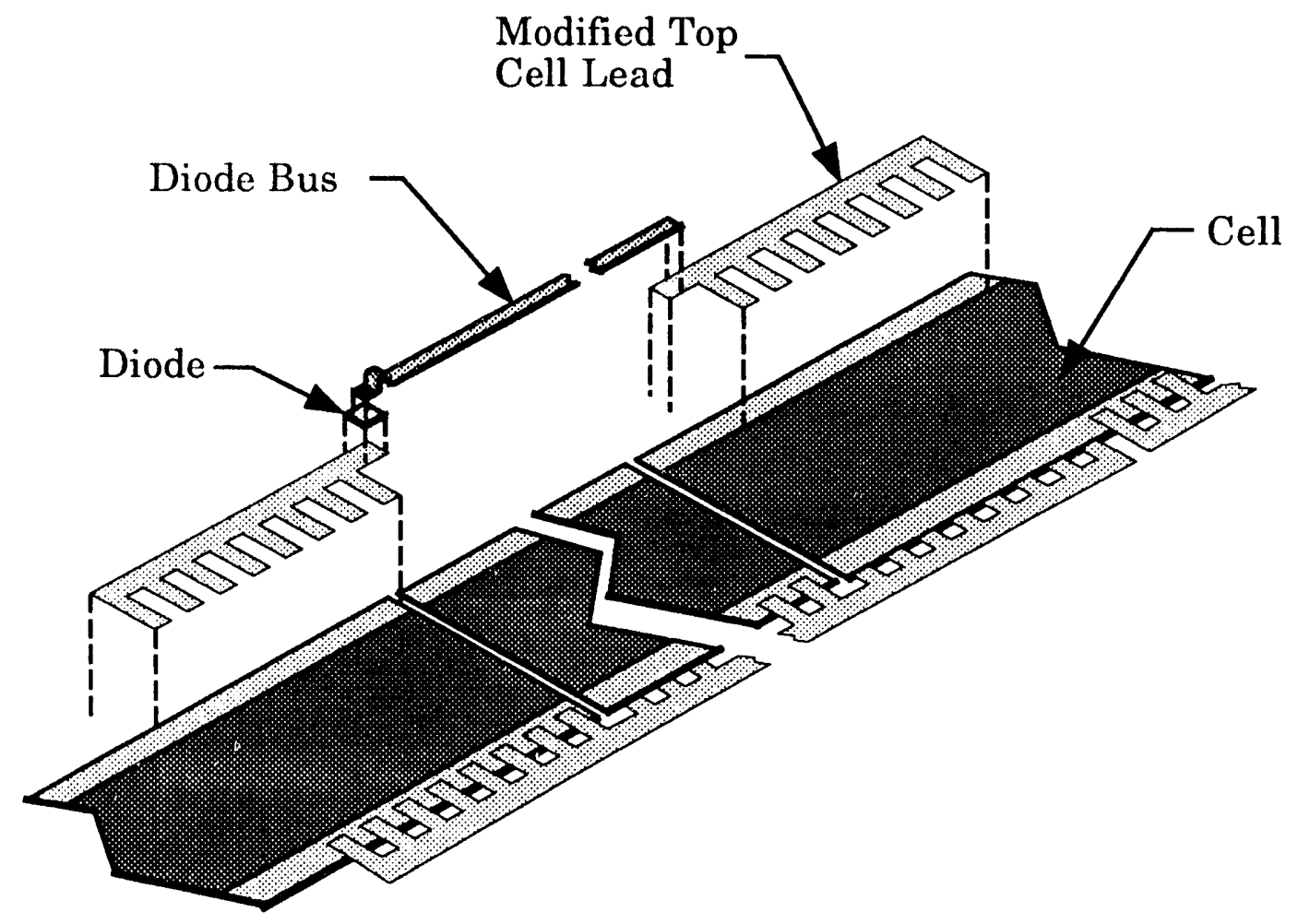

Figure 29. Diode Leads

\subsection{Assembly}

Electrical isolation is provided by a combination of the anodization of the aluminum heat sink and the heat conductive RTV layer. The RTV has a second function, to bond the cells, leads and diodes to the heat sink. There are no mechanical fasteners used.

Emerson and Cuming 4952 Red RTV was used. This has proven to be an effective adhesive in the past.12 The white version of this RTV would be preferable but is no longer available in small quantities.

The cell leads and other cell string components were soldered by hand using a temperature controlled soldering iron. Solder, in addition to the solder plated on the leads, was suppled by using RMA flux core wire silver-tin-lead eutectic solder. The cells were held in position during the soldering by tape on the top surface.

12L.C. Beavis, Evaluation of Some Photovoltaic Concentrator Solar Cell-Heat Sink Coupling Materials, SAND82-2281 (Albuquerque: Sandia National Laboratories, 1984). 
The cell string was cleaned using Tech Spray Flux Stripper S. After soldering, cleaning and bonding the cell string to the heat sink, the top contact to the diode was made using a silver-filled, electrically conductive epoxy. The epoxy was cured at $100^{\circ} \mathrm{C}$ for one hour. The cell string assembly technique used was a hand operation and not representative of a production operation in which fixtures and soldering furnaces would be used.

'T'wo groups of foot-long receivers were assembled. The receivers used a common soldering technique, but different RTV bonding and conformal coating techniques were used.

\subsubsection{First Group}

four receivers were assembled and delivered using the ASEC cells. These receivers had five cells each, connected in series by the cell leads, with one bypass diode connected in parallel with the cell string. No output connectors were supplied with the receivers.

Emerson and Cuming S-11 primer was applied to the heat sinks and cells for this first group of receivers. This was recommended by Emerson and Cuming for use with the Emerson and Cuming 4952 Red RTV used to bond the cells to the heat sinks. Adhesion was found to be inadequate: the RTV could be pulled off of the receivers with little effort. These receivers did not pass the temperature cycling tests at Sandia as described below.

All of the heat sinks for the first group of receivers were sealed with nickel acetate after anodizing. In other testing, adhesion was improved with the S-11 primer on tuat sinks that were sealed as opposed to heat sinks that were not sealed. No difference was found in the electrical standoff from the sealed and non-sealed iseat sinks. No fingerprints were allowed on the heat sinks. No additional deaning was performed after anodizing other than an air wash to remove dust.

(inc layer of RTV was used for the first group of receivers. This was spread to a uniform thickness with a knife edge, and the cells were then applied. The aceivers were cured overnight with weights added to the cells, which applied a mesure of approximately 1 pound per square inch. The RTV was mixed by hand 
with Catalyst 50 at approximately 200:1 RTV:catalyst concentration. The mixture was allowed to stand, prior to use, to allow large air bubbles to come to the surface and pop. No other de-airing techniques were used.

General Electric SR-900 conformal coating was applied to the top surface of the cells and to the cell interconnects on the first group of receivers. This was advertised as equivalent to the Dow Corning 1-2577 recommended by Sandia. However, the Sk-900 remained tacky after curing. The tacky surface is always more inclined to pick up dust and dirt. The conformal coating was applied by brushing. This introduces some small bubbles. A bubble-free application method is being sought for future assemblies. De-airing was tried, but ont-gassing of the volatiles occurred, making matters worse.

\subsubsection{Second Group}

Utilizing the information learned from evaluation of the first group of receiver sections, five receivers were assembled and delivered for the second group. Three of these receivers used five each ASEC cells, as did the receivers for the first group, and two receivers used three each AstroPower one-sun cells. The AstroPower cells were single-bus mechanical samples made by sawing 4 -inch square one-sun cells into four, 1-inch wide by 3.88-inch long cells, see figure 30 .

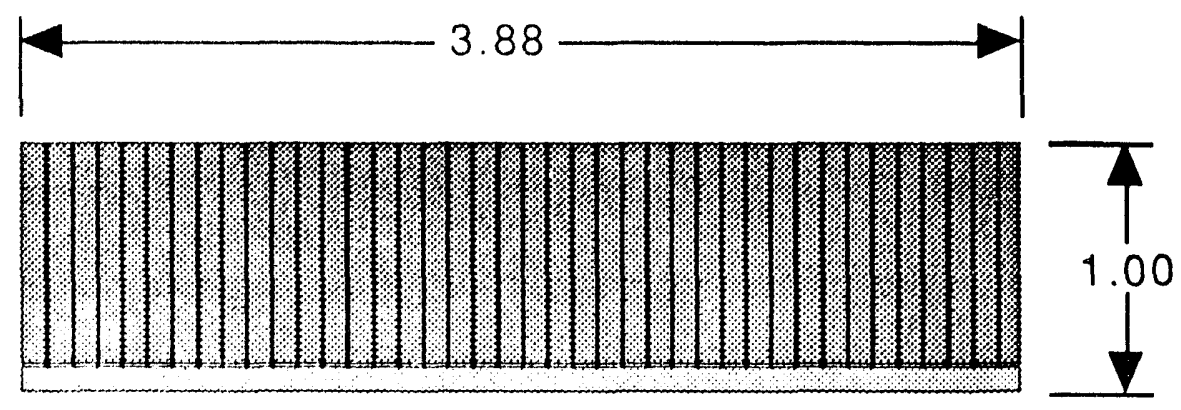

Figure 30. AstroPower Cell

From experience with the first group of receivers, it was apparent that the silver filled conductive epoxy and the relatively stiff top contact did not produce a reliable joint. This is discussed further in Section 3.5, Results, Receiver Development. Therefore, no bypass diodes were installed on the second group of receivers. 
The second group of five, foot-long receivers was assembled utilizing the experienced gained during the assembly and testing of the first group. This was done in lieu of the full size modules. It was decided that further development of the receivers, through the assembly and testing of foot-long sections, would be more beneficial than producing full-size modules.

General Electric SS-4155 primer was was applied to the heat sinks and cells on these receivers. This gives excellent adhesion: it is impossible to remove the RTV from the heat sinks without the use of mechanical scraping and chemical solvents. There is good adhesion to the cells too.

Adhesion was additionally improved by scrubbing the surface of the heat sink with a cotton tipped swab dipped in the primer as opposed to brushing the primer on the surface. One possible explanation for this is the cleaning action imparted by scrubbing. Half the receiver heat sinks were sealed with nickel acetate after anodizing and half were not sealed. No difference in adhesion was noted for the sealed and non-sealed heat sinks with the SS-4155 primer.

The RTV material was unchanged for the second group of receivers. However, the second group was "double dipped." A first layer of RTV was applied in a uniform layer from 0.005 to 0.007 inch thick and cured. The second layer was applied using a "double Y" pattern as described below. The "double-dip" method was adopted to improve the hipot test leakage current, which was marginal for the first group as discussed in Section 3.5, Results, Receiver Development.

A vacuum chamber was used for the second group of receivers to de-air the RTV prior to its being applied. A marked decrease in small air voids, observed when cured samples of the RTV were sectioned, was noted. For production, airless mixing would be used.

A "double Y" pattern was used with the second layer of RTV on the second group of receivers as opposed to a uniformly thick layer on the first group of receivers, ste figure 31. This places the RTV in a position so that it moves from the center to the edges of the cells when pressure is applied, pushing trapped air ahead of the RTV. The RTV was cured overnight at room temperature with approximately 1 pound per square inch pressure applied. As noted below, additional curing was 
done after application of the conformal coating. Cell string assembly was identical for the second and first groups of receivers.

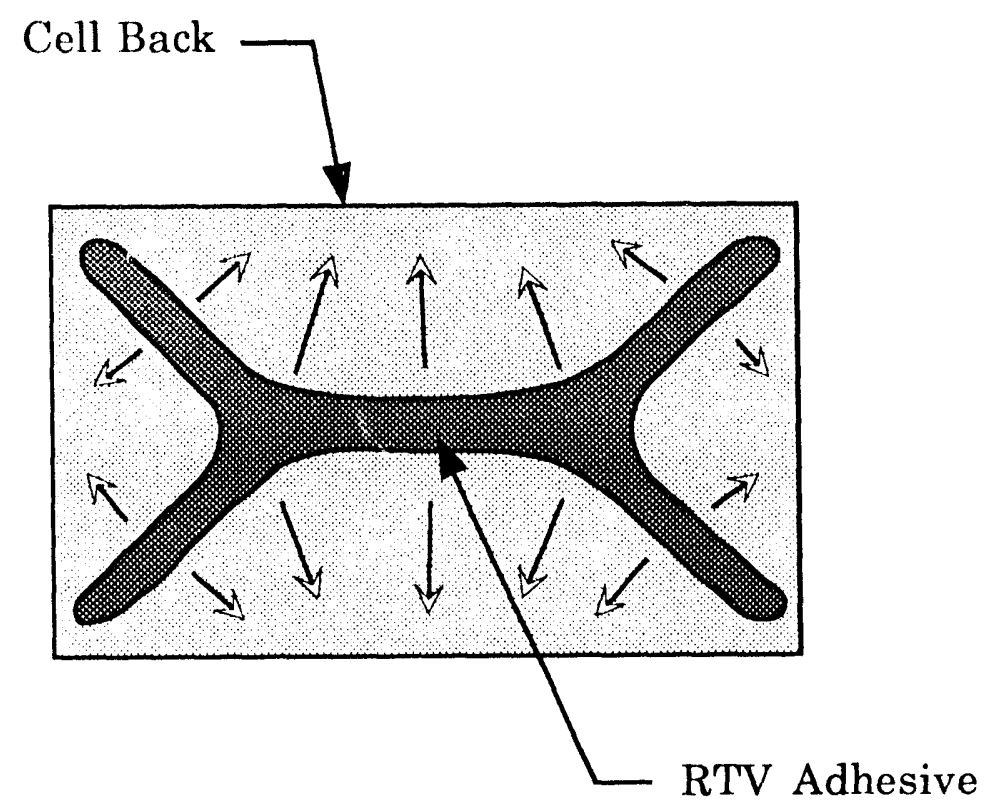

Figure 31. RTV Pattern Used to Exclude Air

One receiver was built using Dow Corning Sylgard 182 silicone coating and alumina powder in a $50 / 50$ mixture by volume. The alumina is $99.98 \%$ pure and screened to 0.3 -micron diameter or smaller. This material is stronger than the 4952 but may not be as thermally conductive. Adhesion was good, but some voids were observed after curing at $100^{\circ} \mathrm{C}$, presumedly caused by out-gassing at the elevated temperature necessary to cure this adhesive.

Dow Corning 1-2577, as recommended by Sandia, was used as the conformal coating for the second group of receivers. The 1-2577 cures without tack. As in the first group of receivers, the conformal coating was applied by brushing. It was allowed to air dry over night.

After the second group of receivers was completed, they were baked in an oven at $100^{\circ} \mathrm{C}$ for one hour minimum. This helps complete the cure of the RTV and expel any remaining volatiles remaining in the conformal coating. The hipot leakage current improves after this process. A summary of the receiver materials can be seen below in table 3 . 
Table 3. Summary of Receiver Assembly Materials

\begin{tabular}{|c|c|c|c|c|c|c|c|c|}
\hline Group & S/N & Sealer & Primer & Cell & RTV & $\begin{array}{c}\text { RTV } \\
\text { Layers }\end{array}$ & Diode & $\begin{array}{c}\text { Conformal } \\
\text { Coating }\end{array}$ \\
\hline 1 & RS1 & Yes & S-11 & ASEC & 4952 & 1 & Yes & SR-900 \\
\hline 1 & RS2 & Yes & S-11 & ASEC & 4952 & 1 & Yes & SR-900 \\
\hline 1 & RS3 & Yes & S-11 & ASEC & 4952 & 1 & Yes & SR-900 \\
\hline 1 & RS4 & Yes & S-11 & ASEC & 4952 & 1 & Yes & SR-900 \\
\hline 2 & 1 & Yes & SS-4155 & AP & 4952 & 2 & No & $1-2577$ \\
\hline 2 & 2 & Yes & SS-4155 & AP & SG 182 & 2 & No & $1-2577$ \\
\hline 2 & 7 & No & SS-4155 & ASEC & 4952 & 2 & No & $1-2577$ \\
\hline 2 & 8 & No & SS-4155 & ASEC & 4952 & 2 & No & $1-2577$ \\
\hline 2 & 9 & No & SS-4155 & ASEC & 4952 & 2 & No & $1-2577$ \\
\hline
\end{tabular}

Notes:

See Text for complete description of materials.

\subsection{Testing}

Testing of the receivers at SEA consisted of a functional electrical test and a hipot test. The function electrical test consisted of measuring the total output voltage and individual cell voltages under one-sun illumination. The hipot test is described below.

The Sandia specification calls for a leakage current of less than $50 \mu \mathrm{A}$ at $2200 \mathrm{Volts}$ DC potential. This specification will have to be met for a full size receiver of 8 -foot length. It was observed that the leakage current was approximately proportional w) the area involved (total area of cells and leads bonded to the heat sink). Thus, fir a 1 -foot long receiver, the leakage current would have to be less than $6.25 \mu \mathrm{A}$ at 2200 volts to be equivalent to a leakage current of $50 \mu \mathrm{A}$ for an 8 -foot long receiver.

The hipot test was done under both dry and wet conditions. The two electrical connections to the cell string were shorted together and to the DC high-voltage surce. The heat sink was connected to the grounded lead. An Associated Rr.search, Inc. D.C. Hypot tester, Model 5212 was used for this test. The test was 
run according to the Sandia Test Specifications for receiver sections. ${ }^{13}$ The voltage was increased, on a dry receiver, at a rate less than $200 \mathrm{volts} / \mathrm{sec}$ to 2200 volts, which was held for 1 minute. Leakage current was recorded. The receiver was then sprayed with tap water and the leakage current observed for 1 minute. leakage current under wet conditions was recorded. Under dry conditions, hipot currents of from $5 \mu \mathrm{A}$ to $12 \mu \mathrm{A}$ were measured for the first group of receivers and from $0.05 \mu \mathrm{A}$ to $1.4 \mu \mathrm{A}$ were measured for the second group of receivers. An average of $0.5 \mu \mathrm{A}$ increase in hipot current was observed for the wet receivers over the dry receivers. Any signs of arcing or flashover were recorded. The results of the hipot tests at Sandia are presented in section 3.5, Results.

After testing at SEA, the receivers were sent to Sandia for evaluation. The receiver sections were evaluated to the qualification test specification for receiver sections and cell assemblies as contained in the Sandia Qualification Tests for Photovoltaic Concentrator Cell Assemblies and Modules (Sandia Qual Tests). ${ }^{14}$ A flow diagram of the test sequence to which the receiver sections were subjected is given in figure 32 .

Before environmental testing, the receivers were subjected to visual inspection and electrical characterization. Ultrasound pictures were also taken in an effort to determine void area before and after testing. Electrical characterization was done outdoors using lenses with sides attached, see figure 33 .

For the first group of receivers, serial numbers RS2 and RS4 were subjected to the full amount of 250 cycles of thermal cycling while receiver serial number RS1 was subjected to the the 10 cycles of humidity/freeze cycling after 60 cycles of thermal cycling. Receiver serial number RS3 was held out as a control.

For the second group of receivers, serial numbers 2 and 8 were subjected to the full amount of 250 cycles of thermal cycling while receiver serial numbers 1,7 and 9 were subjected to the 10 cycles of humidity/freeze cycling after 60 cycles of thermal cycling. Receiver serial number RS3 from the first group was again used as a control.

1:3 See furstnote 7, Section 2.2, High Voltage Standoff 'Test (Hi-Pot).

1.tserefouturte 7 . 


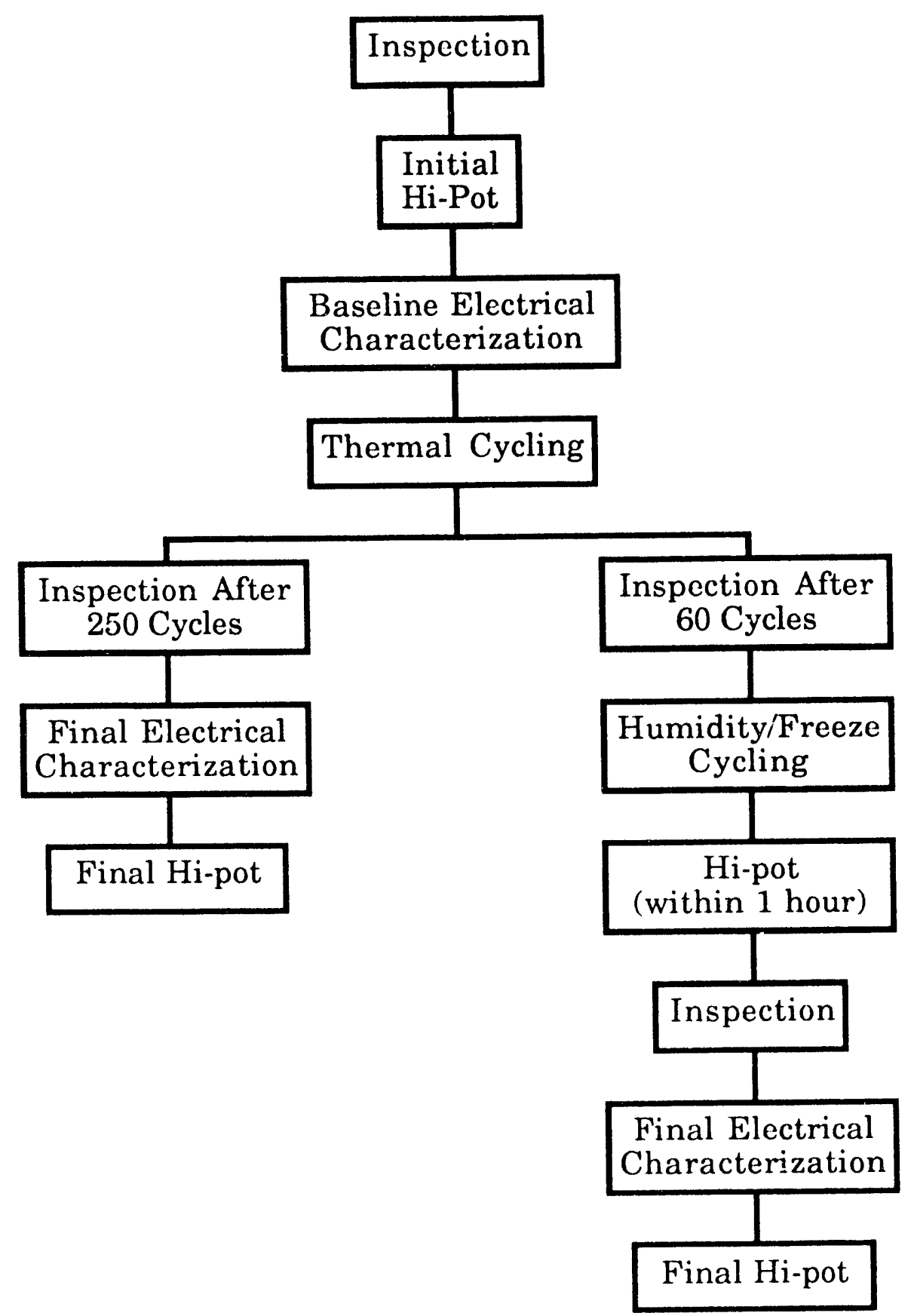

Figure 32. Environmental Test Flow Diagram 


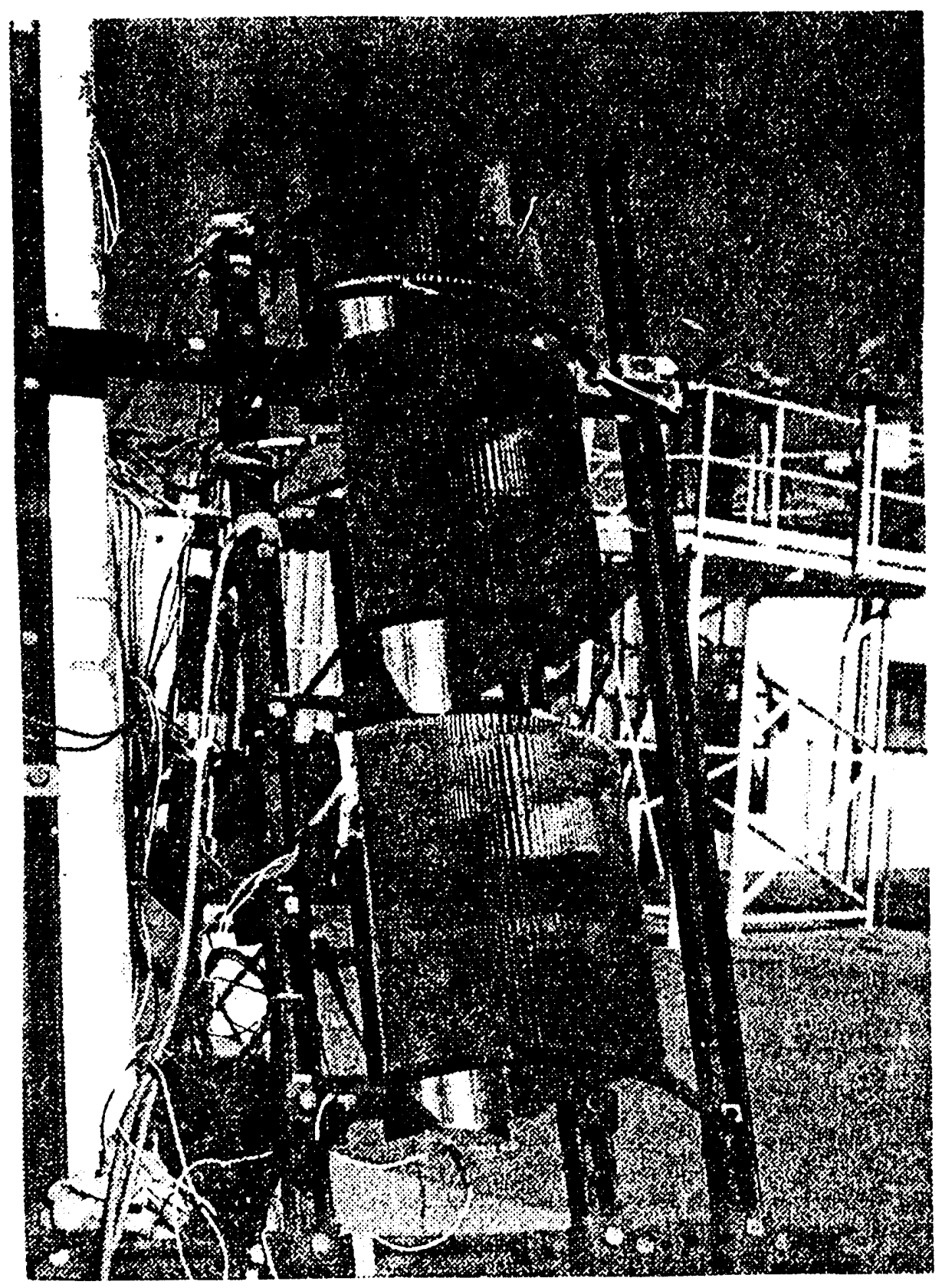

Figure 33, Receivers Under Test 


\subsection{Results}

The results of receiver testing were reported by 2 dia. ${ }^{15}, 16$ A summary of these reports is presented here.

\subsubsection{First Group}

Visual inspection after environmental testing inowed no change. The conformal coating was noted as being sticky during the initial inspection. Postenvironmental electrical tests did reveal some changes. The leakage current during the hipot tests showed improvement for t'nree receivers, but one receiver failed, see table 4 .

Table 4. Receiver Leakage Current at 22, 0 Volts for the First Group of Receivers

\begin{tabular}{|c|c|c|c|}
\hline $\begin{array}{c}\text { Receiver } \\
\text { Number }\end{array}$ & $\begin{array}{c}\text { Before } \\
\mu \mathrm{A}\end{array}$ & $\begin{array}{c}\text { After } \\
\mu \mathrm{A}\end{array}$ & Comments \\
\hline $\mathrm{RS} 1$ & 24 to 13 & 2 & Decreased with time before, steady after. \\
\hline $\mathrm{RS} 2$ & 0.5 & 0 & Steady before, steady after. \\
\hline $\mathrm{R}$ iS3 & 13 to 19 & 1.5 & Fluctuated before, steady after. \\
\hline $\mathrm{RS} 4$ & 20 to 8 & fail & Fail* after 40 seconds. \\
\hline
\end{tabular}

* Exceed $50 \mu \mathrm{A}$ ieakage current specification.

During electrical characterization, cell temperature was calculated based upon open-circuit voltage $\left(\mathrm{V}_{\mathrm{oc}}\right)$ and short-circuit current $\left(\mathrm{I}_{\mathrm{sc}}\right)$. The cell temperature was calculated based upon a formula supplied by Dave King, Sandia Division 6224.17 The calculated cell temperatures are presented in Section 3.2.1.4, Heat Sink Test Results. A thermocouple was also mounted to the heat sink under one of the cells.

${ }^{15}$ Charles B. Stillwell, Evaluation Report, SEA Corperation Receiver Sections. Sandia Contract (j)-4239C: (Photovoltaic Technology Research Division 6224, Sandia National Laboratories, Alluquerque, NM, January 1991).

if Charles B. Stillwell, Evaluation Report, SEA Corporation Receiver Sections, Second (iroul. Sindia Contract Q5 1230C, (Photovoltaic Tuchnology Research Division 6224, Sandia National Laboratories, Albuquerque, NM, April 1991).

iritir footnote 9 . 
Sink l'est Results. A thermocouple was also mounted to the heat sink under one of the cells.

Initial evaluation by ultrasound indicated over $10 \%$ void area under the cells, but further study indicated that ultrasound pictures cannot, at this time, be used to reliably detect voids in resilient-type bonds in receiver sections. ${ }^{18}$ It can, however, be used to detect changes in the bond. Parts of the receivers where the ultrasound pictures had initially indicated voids were sectioned, and no voids were found. On the other hand, when the receivers where the ultrasound pictures had indicated changes (more attenuation) were sectioned, voids were found. It appears now that one receiver, serial number $\mathrm{RS} 2$, from the first group did develop voids during environmental testing. This receiver was one of the two receivers that was subjected to the 250 cycles of temperature shock.

Outdoor electrical performance tests conducted before and after the environmental exposure showed abuut $2 \%$ degradation when compared to the control receiver. This is within the $8 \%$ allowed by the Sandia Qual Tests.

The diode in unit RS4 failed (shorted) during the post-environmental electrical characterization test. This is thought to be due to the fact that the silver-filled epoxy and the tcp contact were stiff and did not respond well to differential thermal expansion present during temperature cycling. During similar testing at SEA, a section of the top portion of the diode broke away, moved relative to the bottom portion, and shorted out the junction. This problem is a non-issue because the diodes and leads subjected to testing were always considered not to be representative of the final configuration. ${ }^{19}$ The diode was removed from the circuit so that the electrical characterization could be completed.

The conclusion from the environmental testing of the first group of receivers was that more effort was needed to reduce the void area, improve the conformal coating and improve the RTV bond adhesion.

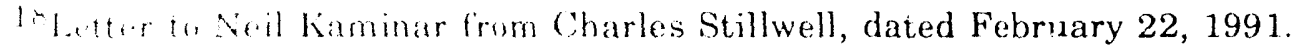

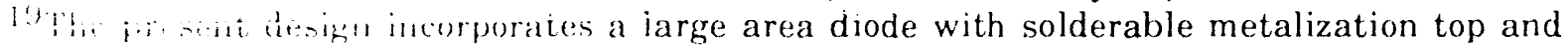
binforn and the top contact has a multiple of flexible connection points. No subsequent similar prohlem. have been experienced to date.
} 


\subsubsection{Second Group}

In general, this second group of five receiver sections looked good. The conformal coating was not tacky, but a few pin-hole size bubbles were observed in the surfaces.

Initial ultrasound pictures indicated a gradual variation in thickness of the RTV, but no significant voids. The gradual variation in RTV thickness is thought to be caused by the bottom contact leads standing off the cells from the heat sink in that area.

The two receivers (\#1\&7) in which the ultrasound pictures showed the widest range in RTV thickness were subjected to the freeze/humidity cycling. ${ }^{20}$ Postenvironmental ultrasound pictures showed a suspicious area under only one cell on only one receiver, serial number 1 . This receiver had the thickest layer of adhesive under the cells. The receiver was sectioned and no void was found. The conclusion was that no voids were formed during the environmental testing.

Hipot leakage currents, both before and after environmental testing, were very good, see table 5. The three receiver sections (\#1, \#7, \& \#9) that were subjected to the humidity/freeze cycles had slightly increased leakage currents, while the units that were subjected to only the temperature shock cycling did not change. Apparently the humidity causes some moisture penetration (moisture absorbed in the RTV). The leakage currents are so small that even for a full-length receiver sections, they would not be over $4 \mu \mathrm{A}$, which is considerably less than the spec level of $50 \mu \mathrm{A}$.

\footnotetext{
20 Ultrasound evaluation with resilient material can be tricky at best. A number of factors can change the attenuation besides thickness or voids: With a filled material, such as the RTV used here, changes in density of the mixture from batch to batch could change the attenuation. Absorbed moisture is also a possible factor. Also, the thickness of the conformal coating is known to change the attenuation.
} 
Table 5. Receiver Leakage Current at 2200 Volts for the Second Group of Receivers

\begin{tabular}{|c|c|c|c|}
\hline $\begin{array}{c}\text { Receiver } \\
\text { Number }\end{array}$ & $\begin{array}{c}\text { Before } \\
\mu \mathrm{A}\end{array}$ & $\begin{array}{c}\text { After } \\
\mu \mathrm{A}\end{array}$ & Comments \\
\hline \hline 1 & $<0.1$ & 0.5 & Steady before, steady after. \\
\hline 2 & $<0.1$ & $<0.1$ & Steady before, steady after. \\
\hline 7 & $<0.1$ & 0.5 & Steady before, steady after. \\
\hline 8 & $<0.1$ & $<0.1$ & Steady before, steady after. \\
\hline 9 & $<0.1$ & 0.5 & Steady before, steady after. \\
\hline
\end{tabular}

Average electrical performance of the second group of receivers degraded an average of $3.65 \%$ after the environmental exposure which is less than the $8 \%$ allowed in the Sandia Qualification Test specifications. The conformal coating on the cells' surfaces showed slight signs of delamination at the interface between the cells. 


\subsection{Updated Costing}

The cost data for the SEA 10X module is entered into an Excelltm spread sheet on a computer. In this way, the cost data can be easily kept up to date.

\subsection{Electrical Energy Costs}

Energy cost is calculated from the formula presented in the DOE Five Year Research Plan 1987-1991, table A-2.

Table 6. Electricity Cost

$\begin{array}{cc}\text { Production Rate, MW/yr } & \text { Energy Cost, EC, } \& / \mathrm{KW}-\mathrm{hr} \\ 1 & 13.1 \\ 10 & 8.1 \\ 100 & 6.0\end{array}$

The economic assumptions taken from Table A-3 of the DOE Five Year Research Plan are as follows:

$$
\begin{array}{ll}
\mathrm{FCR} & =\text { Fixed Charge Rate }=0.091 \text { (constant dullars) } \\
\mathrm{CRF} & =\text { Capital Recovery Factor }=0.073 \\
\mathrm{G} & =\text { Present Worth Factor }=13.7 \\
\mathrm{ID} & =\text { Indirect Cost Factor }=0.5 \\
\mathrm{~S} & =\text { Annual Solar Availability }=2600 \mathrm{KW}-\mathrm{hr} / \mathrm{m}^{2}-\mathrm{yr} \\
\mathrm{IN} & =\text { Average Peak Insolation }=0.85 \mathrm{KW} / \mathrm{m}^{2} \\
\mathrm{OM} & =\text { Yearly Operations and Maintenance Cost }=1.40 \$ / \mathrm{yr} / \mathrm{m}^{2}
\end{array}
$$

The calculated values derived below are as follows:

$$
\begin{array}{ll}
M 1)+A B & =\text { Area related module and } \mathrm{BOS} \text { cost in } \$ / \mathrm{m}^{2} \\
\mathrm{P} B \mathrm{~S} & =\text { Power related cost }=100 \$ / \mathrm{KW} \\
\mathrm{ASE} & =\text { Annual System Efficiency }=9.9 \%(11 \% \text { module } \times 90 \% \text { inverter })
\end{array}
$$

The expanded formula used to calculate energy cost is:

$$
\mathrm{EC}=\frac{(\mathrm{FCR}(1+\mathrm{II}))((\mathrm{MD})+\mathrm{AB})+\mathrm{PB} /(1 /(\mathrm{IN} \times \mathrm{ASE}))))+(\mathrm{G} \times \mathrm{CRF} \times \mathrm{OM})}{\mathrm{S} \times \mathrm{ASE}}
$$




\subsection{Module Performance}

Module performance is based on achievable numbers and in fact is very conservative. Module performance starts with the cells. SEA believes that onesun cells can deliver $16 \%$ efficiency at $10 \mathrm{X}$ geometric concentration at a junction temperature of $28^{\circ} \mathrm{C}$. This is based on conversations with various cell manufactures and in-house testing. At normal operating cell temperature, a $16 \%$ cell efficiency will decline to approximately $15.3 \%$.

Lens transmission used for the cost calculations is $75 \% .21$ A $15.3 \%$ cell operating under a $75 \%$ lens will provide an array efficiency of approximately $11 \%$, after adding in wiring losses. The inverter and array field wiring efficiency is expected to be $90 \%$, reducing the array field output to $9.9 \%$.

The module performance used to calculate the $6 \phi / \mathrm{KW}-\mathrm{hr}$ for the $100 \mathrm{MW} / \mathrm{yr}$ production rate is very conservative. If improved lens transmission ( $85 \%$ vs. $75 \%$ ), improved cell efficiency (17\% vs. $16 \%$ ) and improved inverter efficiency (95\% vs. $90 \%)$ are used, then the energy cost is reduced to approximately $4.6 \% / \mathrm{KW}$-hr at 100 $\mathrm{MW} / \mathrm{yr}$.

\footnotetext{
${ }^{21}$ We have already achicved in excess of $76 \%$ transmission under the work reported here, and subsequent effort has produced lenses of $78 \%$ transmission. Lens transmission is expected to eventually reach over $85 \%$.
} 


\subsection{Summary of Costs}

Costs are summarized in table 7: Costs are with markup and are presented in $\$ / \mathrm{m}^{2}$. Markups are $120 \%$ for the production rate of $1 \mathrm{MW} / \mathrm{yr}, 95 \%$ for $10 \mathrm{MW} / \mathrm{yr}$ and $65 \%$ for $100 \mathrm{MW} / \mathrm{yr}$.

Table 7. Summary of System Costs in $\$ / m^{2}$

Production Rate, MW/yr

\begin{tabular}{lrrr} 
Item & 1 & \multicolumn{1}{c}{10} & \multicolumn{1}{c}{100} \\
\hline Module costs & 194.77 & 110.61 & 77.06 \\
Array costs & 29.63 & 21.51 & 16.69 \\
Field costs & 4.05 & 1.79 & 0.76 \\
Total with markup & 228.45 & 133.91 & 94.51
\end{tabular}

Inverter and field wiring are not included in the above costs but are included in table 6, Electricity Costs. With a insolation rate of $850 \mathrm{~W} / \mathrm{m}^{2}$ and an array efficiency of $11 \%$ (no inverter losses), the total costs in $\$ / \mathrm{W}$ are as shown in table 8:

Table 8. Cost per Watt

Production Rate, MW/yr

1

10

100
Total Installed Array Costs, $\$ / \mathrm{W}$

2.44

1.43

1.01 
Module costs are summarized in table 9: Costs are in $\$ / \mathrm{m}^{2}$

Table 9. Summary of Module Costs

Production Rate, MW/yr

\begin{tabular}{lrrrl} 
Item & \multicolumn{1}{c}{1} & \multicolumn{1}{c}{10} & \multicolumn{1}{c}{100} & Notes \\
Cells & 36.77 & 22.98 & 16.55 & One-sun cells \\
Cell Interconnects & 0.65 & 0.55 & 0.47 & Stampings \\
Diodes \& Wiring & 0.12 & 0.10 & 0.09 & No separate wiring \\
Optics, Primary & 20.23 & 15.63 & 13.79 & Extruded lens \& sides \\
Optics, Secondary & 1.05 & 0.46 & 0.24 & Reflective film \\
Ends, Heat Sink, Glue & 20.50 & 12.40 & 11.41 & No separate housing \\
Module Assembly & 9.21 & 4.60 & 4.15 & \\
Total Module Costs & 88.53 & 56.72 & 46.70 & \\
lotal with Markup & 194.77 & 110.61 & 77.06 &
\end{tabular}

Array costs are summarized in table 10: Costs are in $\$ / \mathrm{m}^{2}$

Table 10. Summary of Array Costs

Production Rate, MW/yr

\begin{tabular}{lrrrl} 
Item & \multicolumn{1}{c}{1} & \multicolumn{1}{c}{10} & \multicolumn{1}{c}{100} & Notes \\
\hline Array Structure & 7.59 & 6.99 & 6.07 & Not tracking, stationary \\
Drive & 5.88 & 4.05 & 4.05 & Including linkage \\
Total Array Costs & 13.47 & 11.03 & 10.12 & \\
T'otal with Markup & 29.63 & 21.51 & 16.69 &
\end{tabular}

Field costs are summarized in table 11: Costs are in $\$ / \mathrm{m}^{2}$

Table 11. Summary of Field Costs

Production Rate, MW/yr

$\begin{array}{lllll}\text { Itrm } & 1 & 10 & 100 & \text { Notes } \\ \text { Installation } & 1.84 & 0.92 & 0.46 & \text { Place, drive 4 pegs, wire } \\ \text { 'Tntal with Markup } & 4.05 & 1.79 & 0.76 & \end{array}$




\subsection{Discussion of Costs}

The SEA concentrator modules use a minimum of parts and are produced and assembled at low cost. It was designed from the inception as a commercial product. Installation is simple and low cost. The arrays are shipped preassembled with the legs attached but rotated flat. As each array is unloaded, the two legs are rotated vertically, and the array is placed on a reasonably flat surface. Four fasteners are then installed at the corners of the array frame, through the supports, to secure the unit. Simple electrical connections complete the installation. Up to four arrays share a common tracking unit.

The lens is the most expensive component in most concentrators because of the manufacturing cost. The SEA lens is less than $1 / 3$ the cost of the nearest competitor's. 'This is because of the inexpensive extrusion process. The module sides are planned to be also formed as part of the lens extrusion.

'The tracker drive is simple and direct. Only a single drive is required. Each array can be operated totally independently or in groups up to 4. No separate tracker control is required.

Costing is based on conservative estimates from reliable sources. If errors are present, they are on the high side. Contingencies are added at each stage of the costing. SEA believes that this is the most cost-effective concentrator design available today and that the SEA module has the best chance of exceeding the DOE goals. 


\subsection{Conclusions and Recommendations}

The lens transmission measured under this contract was over $76 \%$, exceeding the program goal of $75 \%$. This transmission was measured at a concentration ratio of approximately 8.9:1. Because the extrusion process is the least costly manufacturing process available to make lenses, the lens development effort should be continued with a new goal of over $80 \%$ transmission at 10:1 concentration. SEA believes that this can be achieved by refining the form of the facets as molded and by polishing the extrusion die.

Calculated lens transmission numbers are higher than measured. A provision to model the "as-molded" geometry of the lens needs to be added to the existing raytrace computer program.

Except for the lack of bypass diodes, the second group of receiver sections performed very well in the evaluation test to which they were subjected. The results indicate that SEA Corporation is well on the way to having a receiver that will pass the full qualification test. Additional work is needed to define a costeffective and robust diode assembly and output connectors.

Calculated cell junction temperatures are much higher than measured. The finite-element heat-transfer computer program needs complete revision to improve its accuracy.

Full size modules, representative as much as possible of proposed production modules, should be tested as soon as possible. Endurance modules should be placed outdoors in an operating mode as soon as possible.

Low-cost one-sun cells, with screened metalization, should be manufactured and evaluated. Alternative low-cost cell manufacturing techniques should be reviewed.

Full size arrays should be assembled after the module testing is completed. Demonstration projects and pilot production should be done after the full-size arrays are built. Production techniques need to be addressed and adopted as soon as possible. 
Appendix A

SEA $10 \times$ Concentrator Drawings 


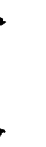




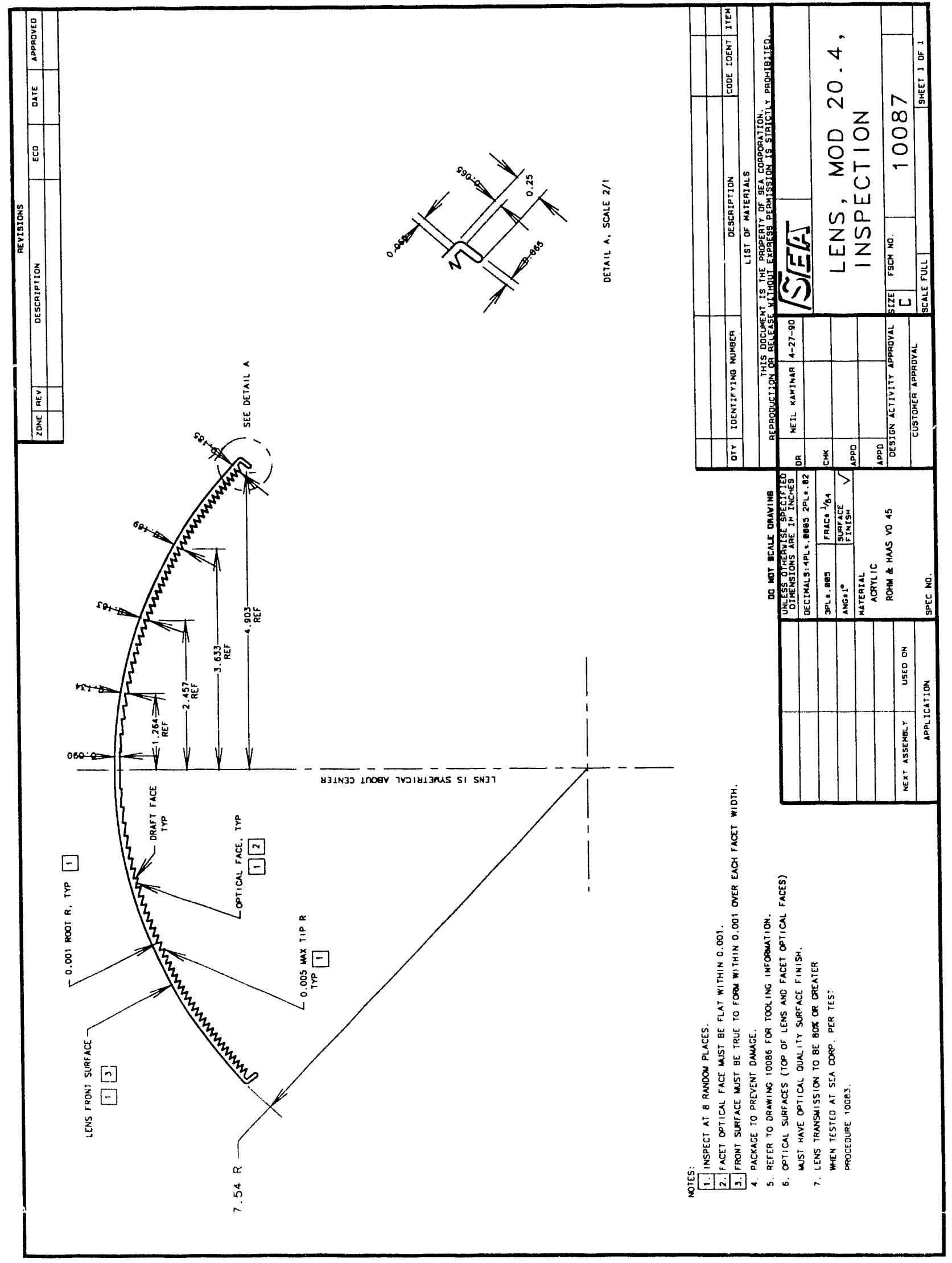




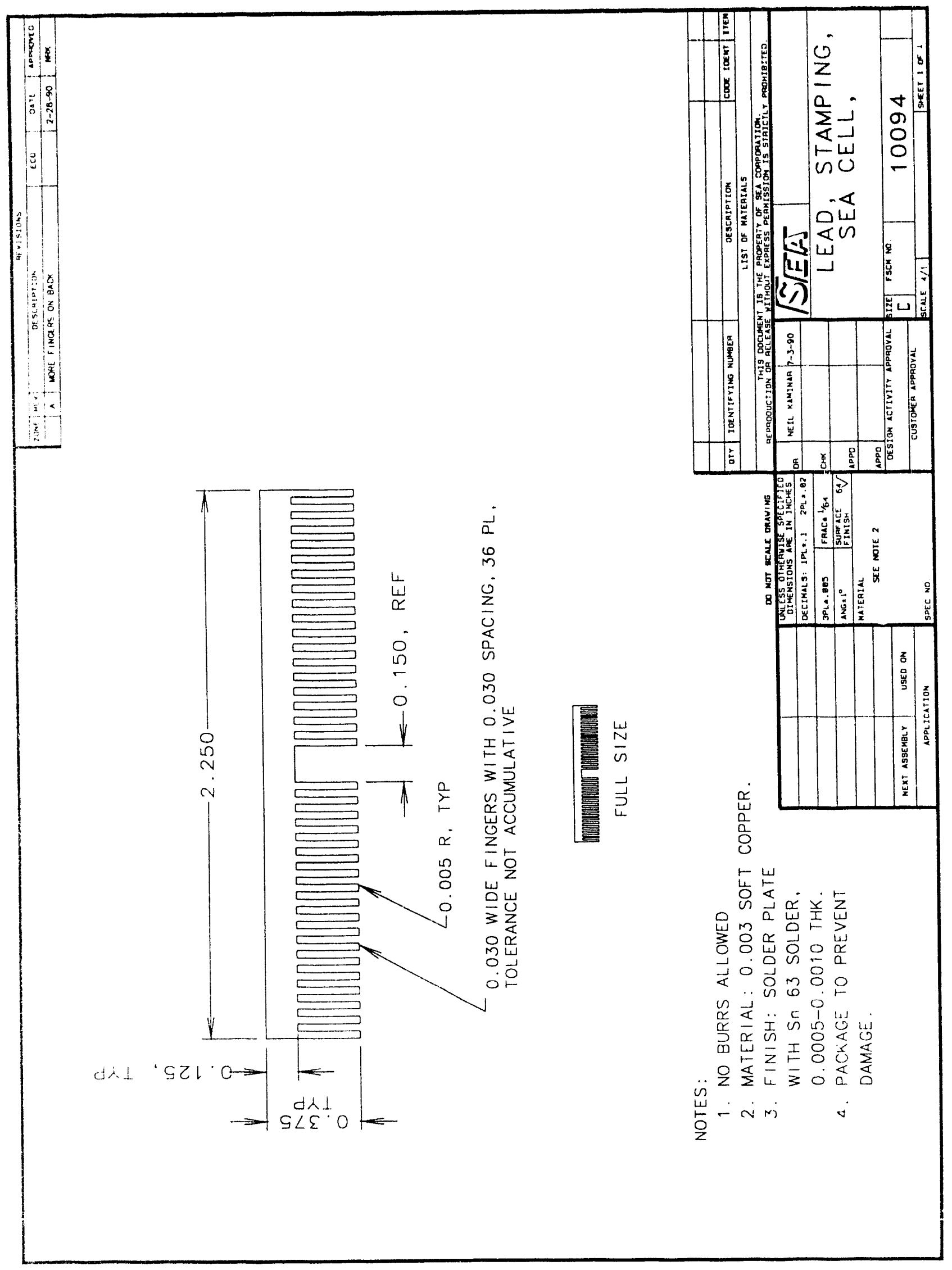




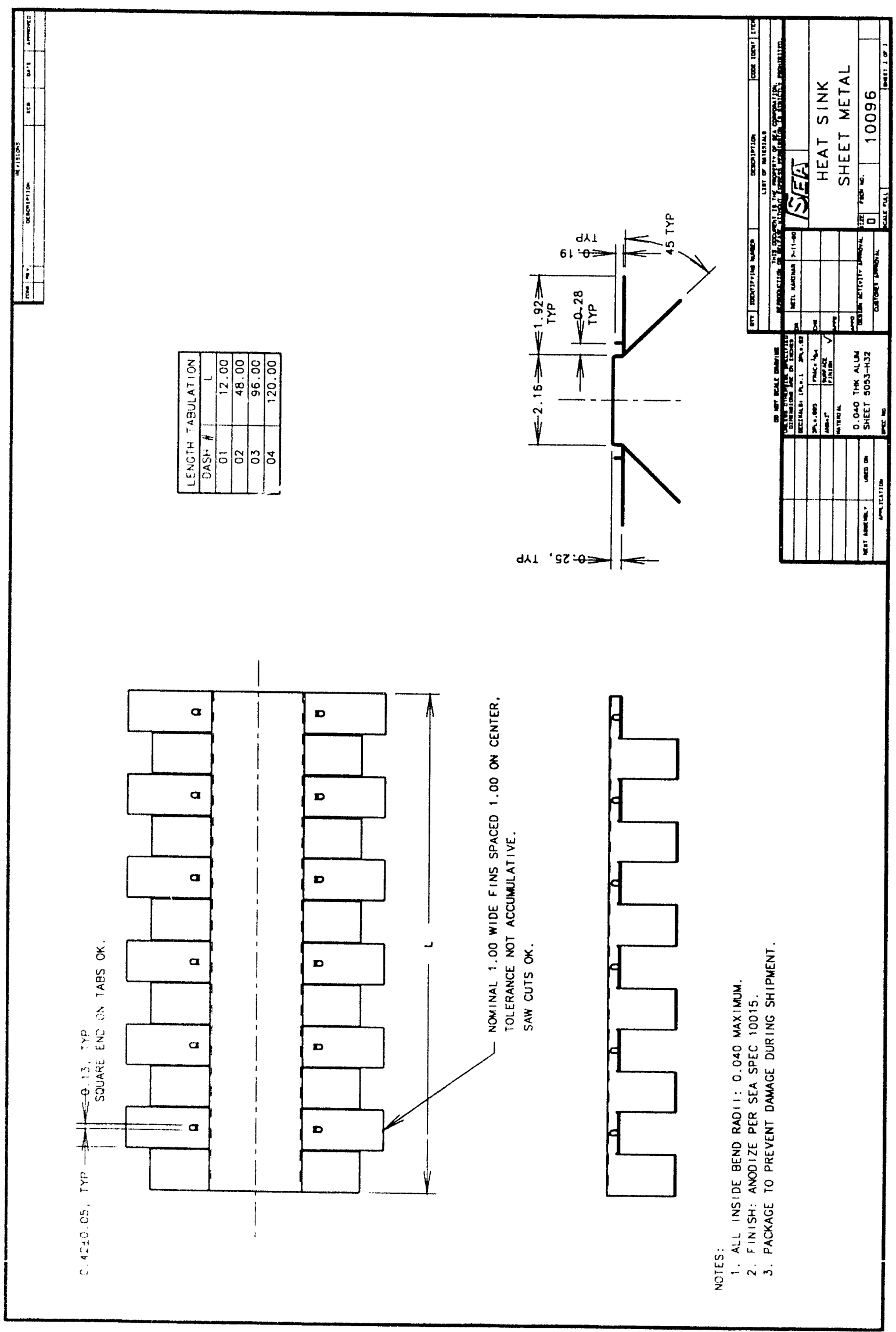




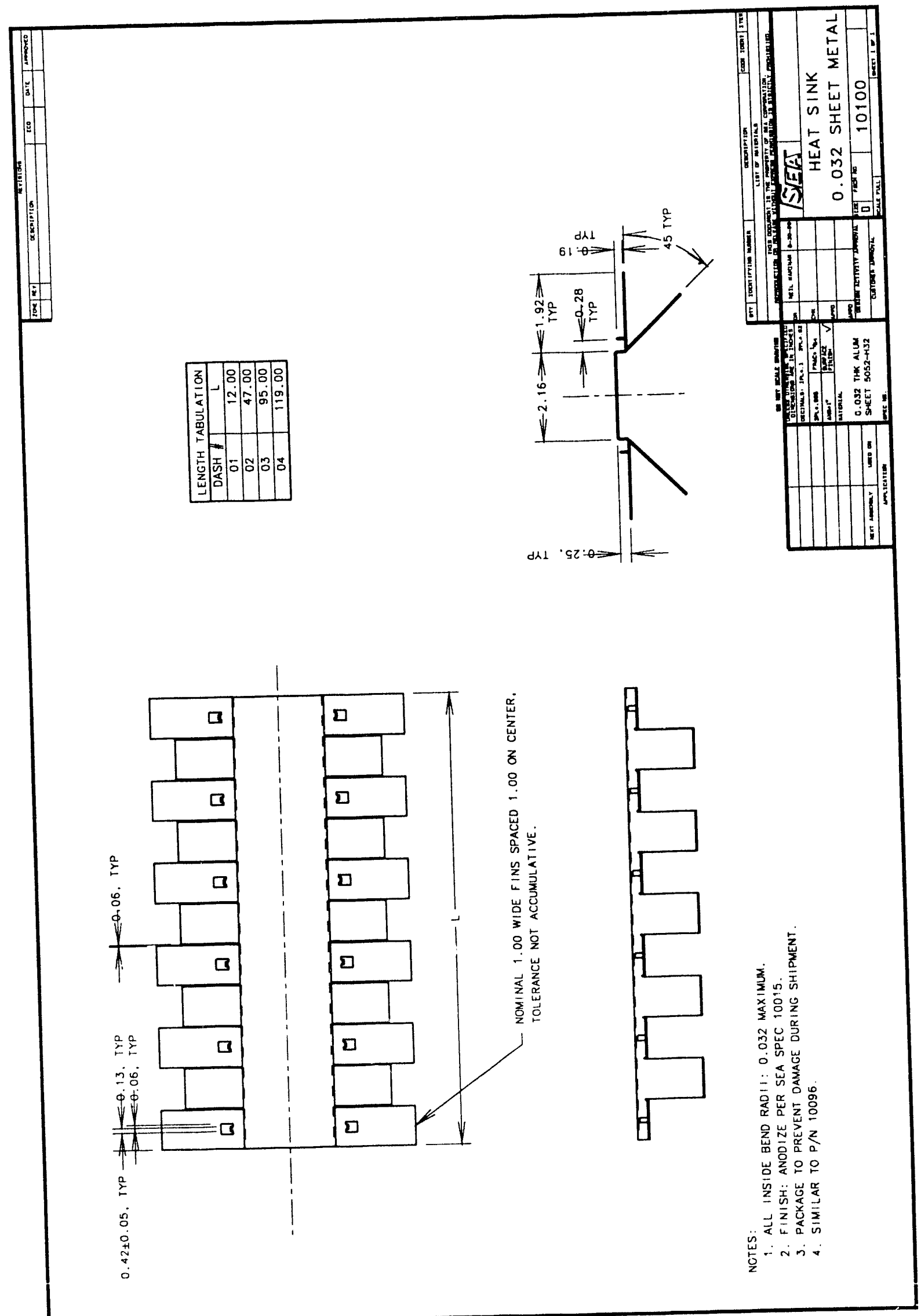




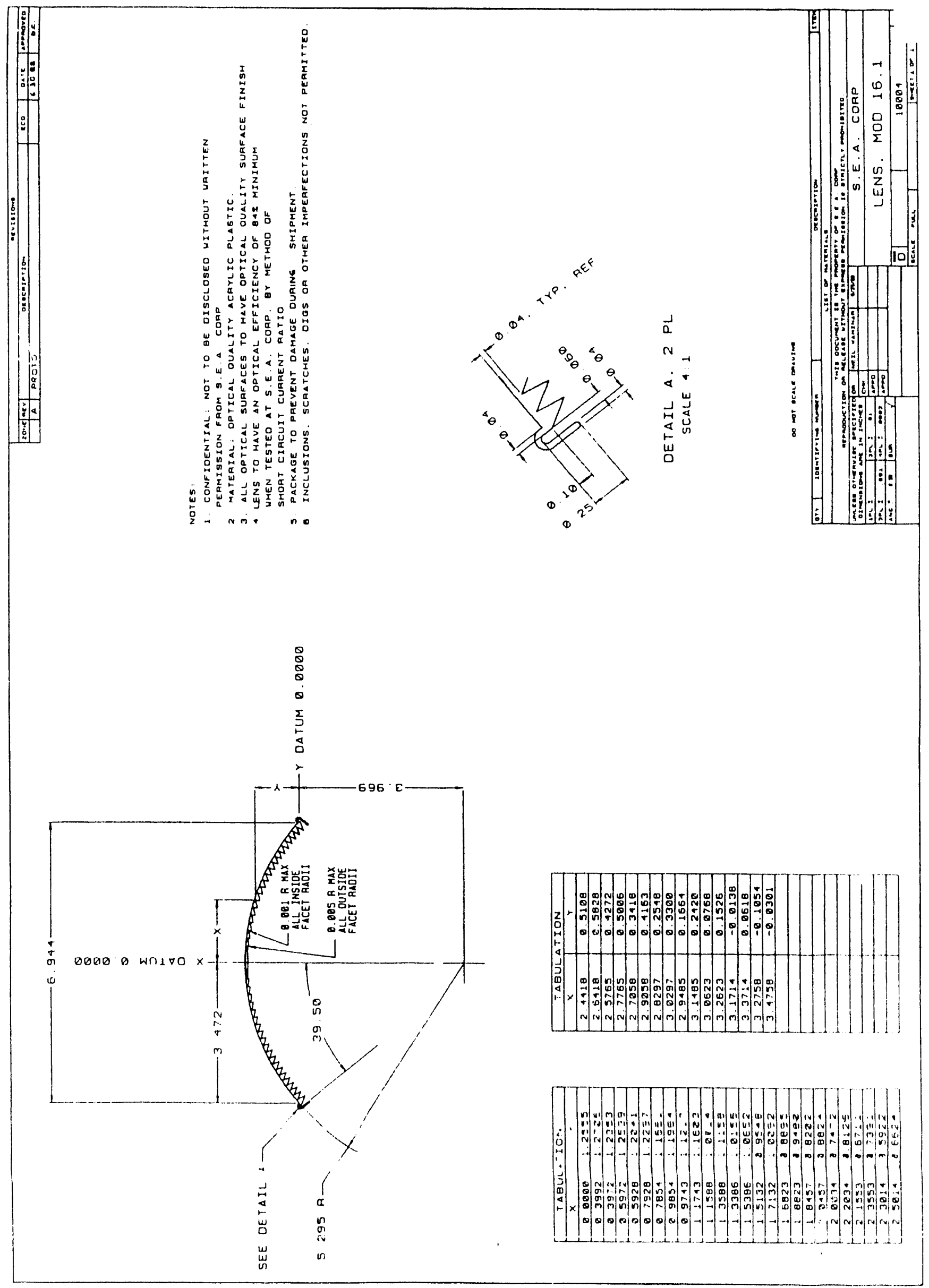




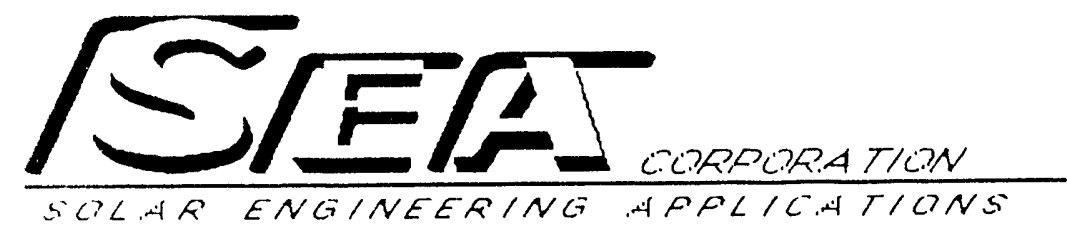

SEA Corp. Specification 10015

Electrical Isolation Anodizing

History

$2 / 08 / 89$

$10 / 12 / 90$

Release

Added water rinse, caustic rinse and finger print warning.

\section{Purpose}

Anodizing applied per this specification will be primarily used for electrical isolation of solar cells from aluminum heat sinks. A secondary function of this anodizing is for protection of the aluminum from the environment.

\section{Silectrical Isolation}

The anodizing must provide an electrical isolation of 2200 volts when used in conjunction with a silicon RTV rubber.

Testing

Electrical isolation will be determined at SEA Corp. with a High Voltage Standoff Test (Hi-Pot) as follows:

A one inch diameter copper disk will be bonded to the anodized aluminum sample with Emerson \& Coming 4952 heat conductive RTV. The RTV will extend a minimum of 0.25 inch beyond the copper disk. Voltage will be applied at a rate not to exceed 200 Volts per sec up to 2200 volts. Leakage of dc current will be monitored and recorded and must not exceed $50 \mu \mathrm{A}$. If the $50 \mu \mathrm{A}$ limit is reached, the corresponding voltage will be recorded.

\section{Environmental}

The anodizing will be required to survive and protect the aluminum for 30 years. Maximum and minimum temperatures are $130^{\circ} \mathrm{F}$ and $0^{\circ} \mathrm{F}$ respectively. Annual rainfall will not to exceed 60 inches per year. No salt air will be encountered.

Color

The anodizing will be died black.

Rinsing

After anodizing, the part will be rinsed in cold water for a minimum of 30 minutes

followed by a hot water rinse for a minimum of 30 minutes.

\section{Finger prints}

No finger prints are permitted on the part.

Preanodizing rinse

Before anodizing, the part will be cleaned followed by a caustic rinse. 


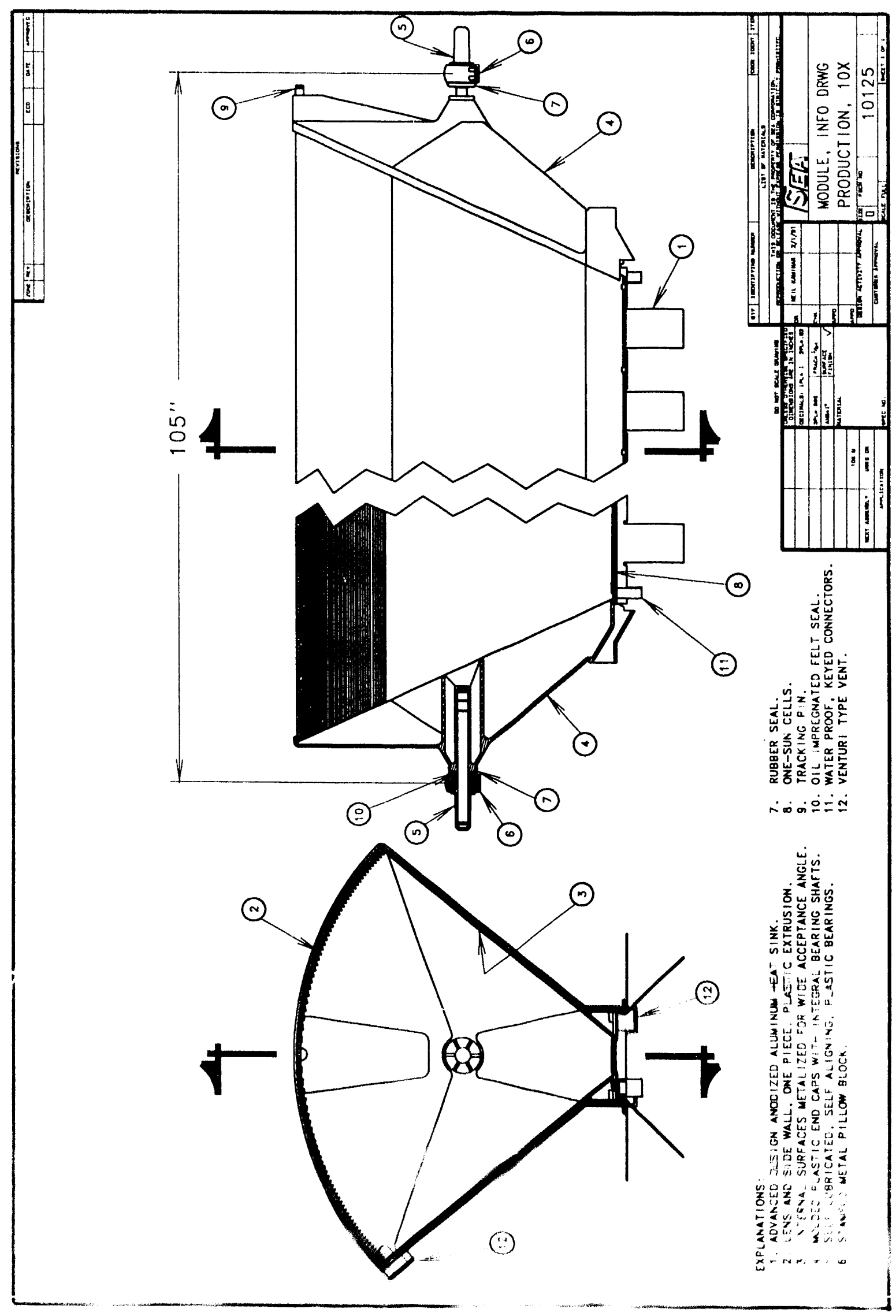


DISTRIBUTION :

AESI

Attn: William J. Todorof $1001 \mathrm{w}$. 17th Street, Unit V Costa Mesa, CA 92627

Alpha Solarco (2)

Attn: Edward Schmidt Don Carroll

11534 Gondola Drive

Cincinnati, OH 45241

Alternative Sources of Energy

Attn: Larry stoiaken

$107 \mathrm{~S}$. Central Avenue

Milaca, MN 56353

American optical Corporation

Attn: Clark Grendol

R. F. Woodcock

14 Mechanic street

Southbridge, MA 01550

Amonix, Inc. (2)

Attn: Vahn Garboushian Sewang Yoon

3545 West Lomita Boulevard

Unit $A$

Torrance, CA 90505

Applied Solar Energy Corp (3)

Attn: Ken Ling

Frank Ho

Peter Iles

15251 E. Don Julian Road

City of Industry, CA 91746

Arizona Public Service Company

Attn: Tom Lepley

P. O. Box 53999

Mail station 3875

Phoenix, AZ 85072-3999

Arizona State University (2)

College of Engineering and Applied Science

Attn: Charles Backus

G. Schwuttke

Tempe, AZ 85287
Astropower Division (2)

Attn: A. Barnett

R. Hall

30 Lovett Avenue

Newark, DE 19711

Austin, City of

Electric Dept.

Attn: John E. Hoffner

P. O. Box 1088

Austin, TX 78767

Bechtel National, Inc.

Attn: Walter J. Stolte

Mail stop 50/15/D17

P. O. Box 3965

San Francisco, CA 94119

Black \& Veatch (2)

Attn: Larry stoddard

Kevin Kershen

P. O. Box 8405, Bldg. P

Kansas City, MO 64114

Boeing Electronics Company

Attn: Lewis Fraas

P. O. Box 24969, MS 9Z-80

seattle, WA 98124-6269

Electric Power Research Inst. (2)

Attn: Frank Goodman Ed DeMeo

3412 Hillview Avenue

P. O. Box 10412

Palo Alto, CA 94303

ENTECH, InC. (2)

Attn: Walter Hess

Mark O'Neill

P. O. Box 612246

DFW Airport, TX 75261

Fresnel optics, Inc.

Attn: John R. Egger

1300 Mt. Read Blvd.

Rochester, NY 14606

Georgia Institute of Technology (2)

School of Electrical Engineering

Attn: Professor Ajeet Rohatgi Richard King

Atlanta, GA 30331 
High Intensity Photovoltaics, Inc. Attn: Bernard L. Sater 9007 Westlawn Blvd.

Olmsted Falls, OH 44138

Hughes Research Labs (2)

Attn: S. Kamath

R. Loo

3011 Malibu Canyon Road

Malibu, CA 90265

Institute of Advanced

Manufacturing Sciences, Inc.

Attn: Paul R. Warndorf

1111 Edison Drive

Cincinnati, OH 45216

James Associates

Attn: Larry James

7329 Meadow Court

Boulder, CO 80301

Jet Propulsion Laboratory

Attn: Ron Ross

R. S. Sugimura

4800 Oak Grove Drive

Pasadena, CA 91109

Kopin Corporation

Attn: M. Spitzer

695 Myles Standish Blvd.

Taunton, MA 02780

Luz Engineering Corp.

Attn: David Kearny

924 Westwood Bivd., Suite 1000

Los Angeles, CA 90024

MT'T/Lincoln Lab

Attn: George Turner

Box 73

Lexington, MA $021 \% 3$

Mobil Solar Energy corporation

Attn: Juris Kalejs

4 Suburban Park Drive

Billerica, MA 01821

New Mexico State University (2)

Attn: L. Matthews

G. Mulholland

P. O. Box 3450

Las Cruces, NM 88003
NYSERDA

Attn: Burton Krakow

Two Rockefellar Plaza

Albany, NY 12223

Oak Ridge National Laboratory (2)

Attn: R. F. Wood

R. D. Westbrook

P. O. BOX Y

Oak Ridge, TN 37830

Pacific Gas \& Electric (3)

Attn: Steve Hester

Carl Weinberg

Christina Jennings

3400 Crow Canyon Road

San Ramon, CA 94583

Pacific Gas \& Electric

Attn: Brian Farmer

Electrical Engineering Dept.

Room F 1126

one California street

San Francisco, CA 94106

Public Service Company of New Mexico

Attn: R. Frank Burcham

Alvarado Square, MS 0150

Albuquerque, NM 87158

Purdue University

Attn: Richard Schwartz

School of Electrical Engineering

West Lafayette, IN 47907

Science Applications International Corporation

Attn: Roger L. Davenport

10343 Roselle street, suite G

San Diego, CA 92121

SERI (3)

Attn: J. Benner

T. Surek

E. Witt

1617 Cole Blvd.

Golden, Co 80401 
SERI Library

1617 Cole Blvd.

Golden, CO 80401

Siemens Solar (2)

Attn: Charles Gay

Kim Mitchell

P. O. Box 6032

Camarillo, CA 93010

Solar Engineering Applications corporation

Attn: D. Curchod

N. Kaminar (10)

2010 Fortune Drive, Suite 102

San Jose, CA 95131

Solar Kinetics, Inc.

Attn: Gus Hutchison

rost office Box 540636

Dallas, TX 75354-0636

Solarex Corporation (2)

Attn: J. Wohlgemuth

Mohan Narayanan

630 Solarex Court

Frederick, MD 20701

SOLEC International, Inc.

Attn: Ishaq Shahryar

12533 Chadron Avenue

Hawthorne, CA 90250

Southern California Edison

Attn: Nick Patapoff

2244 Walnut Grove Avenue

Rosemead, CA 91770

Sparta

Attn: Ugur Ortabasi

56,73 W. Las Positas Blvd.

iite 205

Peasonton, CA 94566

\section{SPECO}

Attn: Walt Hart

P. O. Box 91

Morrison, CO 80465

spectrolab

Atton: D. Lillington

12500 Gladstone Avenue

Sylmar, CA 91342
Spire Corporation (2)

Attn: M. J. Nowlan

S. P. Hogan

Patriots Park

Bedford, MA 01730

Springborn Laboratories, Inc.

Attn: Bernard Baun

Enfield, CT 06082

SunPower Corporation

Attn: Richard Swanson

435 Indio Way

Suite 100

Sunnyvale, CA 94086

3M Company

Solar Optical products

Attn: Paul Jaster, 225-2N-06

3M Center

st. Paul, MN 55144

U. S. Departinent of Energy (2)

Albuquerque, Operations office

Attn: G. P. Tennyson

N. D. Lackey

P. O. Box 5400

Albuquerque, NM 87115

U. S. Department of Energy (6)

Attn: Robert Annan

Morton Prince

James Rannels

Lloyd Herwig

Richard King

Eldon Boes

1000 Independence Ave.

washington, D.C. 20585

University of Arizona

Solar \& Energy Research Facility

Attn: D. E. Osborn

CE Bldg. \#76

Tucson, AZ 85721

University of Chicago

Attn: Joseph O'Gallagher

5640 South Ellis Avenue

Chicago, IL 60637 
University of New Mexico/NMERI

Attn: G. Leigh

Campus Box 25

Albuquerque, NM 87131

VS Corporation

Attn: G. Virshup

611 Hansen Way, MS K-124

Palo Alto, CA 94303

Wattsun

Attn: John Doherty

P. O. Box 751

Albuquerque, NM 87103

Westinghouse Electric Corporation

Attn: Charles Rose

P. O. Box 10864

Pittsburgh, PA 15236

Wright Patterson AFB

Attn: Jack Geis

AFWAL/POOC

Wright Patterson AFB, OH

$\begin{array}{ll}3141 & \text { S. A. Landenberger (5) } \\ 3145 & \text { Document Processing for } \\ & \text { DOE/OSTI (8) } \\ 3151 & \text { G. C. Claycomb (3) } \\ 6000 & \text { D. L. Hartley } \\ 6200 & \text { B. W. Marshall } \\ 6220 & \text { D. G. Schueler } \\ 6224 & \text { D. E. Hasti } \\ 6224 & \text { D. L. King } \\ 6224 & \text { J. E. Cannon } \\ 6224 & \text { T. D. Hund } \\ 6224 & \text { A. B. Maish } \\ 6224 & \text { M. L. Whipple } \\ 6224 & \text { J. R. Woodworth } \\ 6224 & \text { C. B. Stillwell (5) } \\ 6224 & \text { PV Library (5) } \\ 6223 & \text { G. J. Jones } \\ 6223 & \text { M. G. Thomas } \\ 6223 & \text { H. L. Post } \\ 6223 & \text { R. C. Pate } \\ 8523 & \text { Central Technical Files }\end{array}$



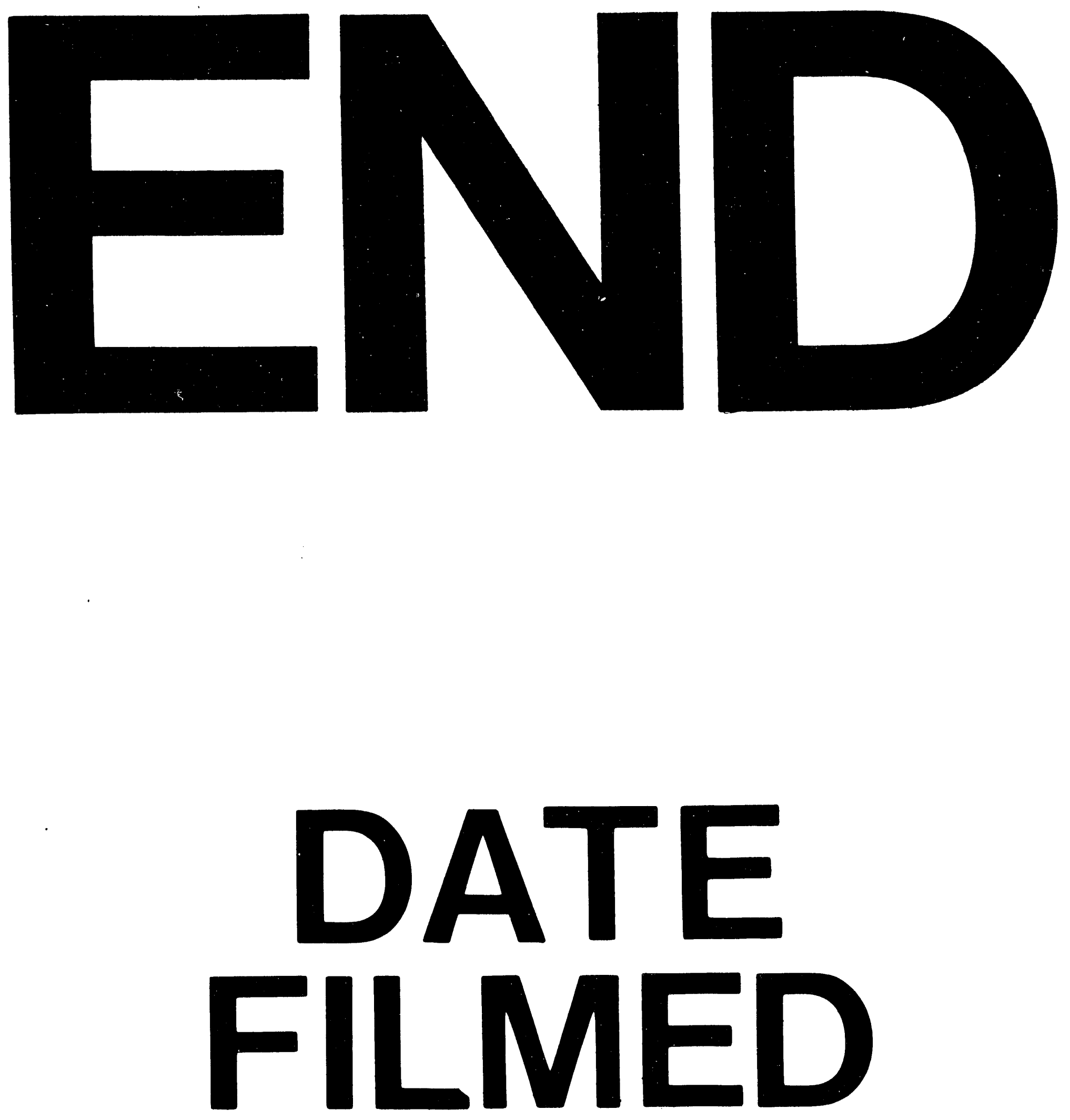

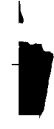

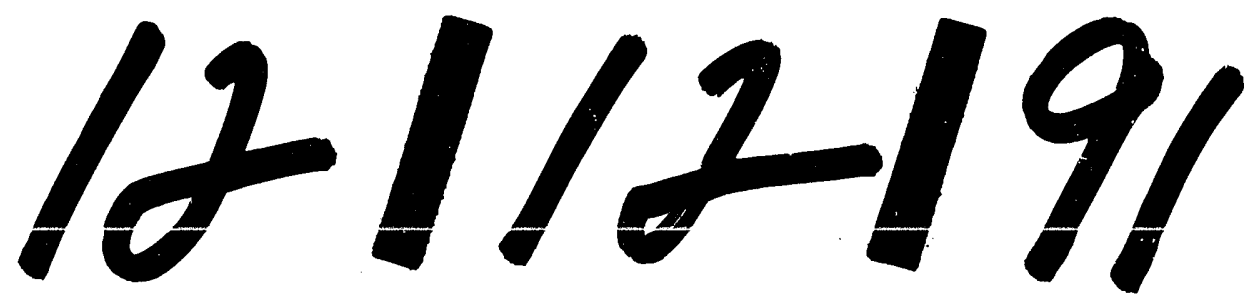

T" 
